\title{
Defining the origins of multiple emission/excitation in Rhenium- bisthiazole complexes
}

\author{
Nicholas Azzarelli, ${ }^{a}$ Shashikanth Ponnala, ${ }^{b}$ Alexander Aguirre, ${ }^{a}$ Sara J. Dampf, ${ }^{a}$

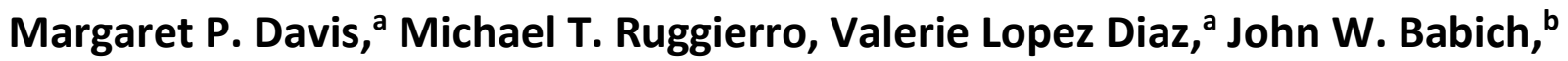 \\ Michael P. Coogan, ${ }^{\mathrm{C}}$ Timothy Korter, ${ }^{\mathrm{a}}$ Robert P. Doyle, ${ }^{\mathrm{a}}{ }^{*}$ Jon Zubieta, ${ }^{\mathrm{a}}$
}

a Department of Chemistry, Syracuse University, Syracuse, NY 13244 USA; b Division of Radiopharmaceutical Sciences and, Department of Radiology, Weill Cornell Medicine, New York, NY, USA; c Department of Chemistry, University of Lancaster, Lancaster, UK LA1 4YB

\begin{abstract}
The underlying mechanism of the unusual emissive behavior of $\left[\operatorname{Re}(\mathrm{CO})_{3}-1,1-\right.$ bisthiazole-(1,4)-diaminobutane)] bromide (4-BT) has been investigated. Synthesis and spectroscopic characterization of structurally similar isomers ([Re(CO) 3 -1,1-bis-2-thiazole-(1,4)diaminobutane)] bromide (2-BT) and , location of triplet states, solid state and low temperature spectroscopic measurements, and DFT calculations show that the photophysical properties are not due to photoisomerization as previously hypothesized. The results show that the unusual emissive behavior is not observed in structural isomers, is specific to the previously reported complex, 4-BT, and may arise from vibrational energy relaxation and vibrational cooling. Translation of the unusual emissive behavior to the solid state offers an interesting platform allowing this complex to be potentially utilized as a probe, sensor or photonic device.
\end{abstract}




\section{Introduction}

Luminescent transition metal complexes incorporating chromophoric conjugated ligands have received considerable contemporary attention because of their attractive photophysical properties ${ }^{1,2}$ and their potential applications as probes, sensors and photonic devices. ${ }^{3}$ The useful properties of such materials include long luminescence lifetimes, large Stokes shifts and resistance to photobleaching. ${ }^{1,4,5}$

Within this general area of luminescent transition metal compounds, those containing the rhenium tricarbonyl core, $\left\{\operatorname{Re}(\mathrm{CO})_{3}\right\}^{+}$, have been extensively explored because of their intrinsically attractive photophysical and biological properties. ${ }^{6-29}$ While the photophysical characteristics of these complexes have been described in terms of the excited states: metal-toligand charge transfer (MLCT), ligand-to-ligand charge transfer (LLCT), and intraligand (IL) states, the MLCT character predominates. The most extensively studied class of rhenium tricarbonyl compounds are the $\left[\operatorname{Re}^{\prime}(C O)_{3}(\mathrm{LL}) \mathrm{X}\right]$ complexes, where $\mathrm{LL}$ is a bidentate diimine ligand or two monodentate pyridyl ligands and $\mathrm{X}$ is a halogen, alkyl group or nitrogen donor ligand.

The $\left[\operatorname{Re}(\mathrm{CO})_{3}(\mathrm{LL}) \mathrm{X}\right]$ compounds have been shown to be effective for elucidating the various excited state properties. The complexes are robust, and incorporation of different Xligands is facile. The systematic tuning of the electronic properties of the complexes is readily achieved by varying the substituents on the diimine ligand. The emission from these complexes generally occurs from triplet metal-to-ligand charge transfer ( $\left.{ }^{3} \mathrm{MLCT}\right)$ excited state, as a result of rapid vibrational relaxation and intersystem crossing from higher vibrational energy levels. As a result, the identity of the lowest energy $\pi$-acceptor ligands is an important determinant in the photophysical properties. Such complexes can be highly emissive $\left(\Phi_{\mathrm{em}}=0.001-0.1\right)$ and often display long lifetimes (10 ns to $1 \mu \mathrm{s}$ ) in solution due to the triplet MLCT. 
A particularly attractive application of the luminescence properties of $\left\{\operatorname{Re}(\mathrm{CO})_{3}\right\}^{+1}$-core complexes is the potential to combine and contrast data from complementary imaging techniques such as the correlation of nuclear and fluorescence imaging to relate deep-tissue whole-body imaging with histopathology and fluorescence microscopy to provide insights into mechanisms of binding, selectivity and cellular distribution of targeted radiopharmaceuticals. In this respect, over the past decade we have introduced and developed a novel approach for the preparation of labeled peptides, exploiting the coordination chemistry of the $\mathrm{M}(\mathrm{CO}){ }_{3}{ }^{+}$core and amino acid based bifunctional chelates. The design of these bifunctional single amino acid chelates (SAAC) exploits the modification of a natural or synthetic amino acid to incorporate a tridentate terminus and a terminus for attachment to small peptides at variable positions within the backbone (Scheme 1). ${ }^{30-64}$ A useful feature of the SAAC approach is the ability to prepare luminescent probes based on the $\operatorname{Re}(\mathrm{CO})_{3}{ }^{+}$core, allowing the design of complementary pairs of fluorescent and radioactive probes. This in vitro/in vivo pairing allows the assessment of the fate of the imaging agent at the cellular level in real time and the evaluation of mechanisms relevant to cellular localization and specificity. ${ }^{37,65-67}$

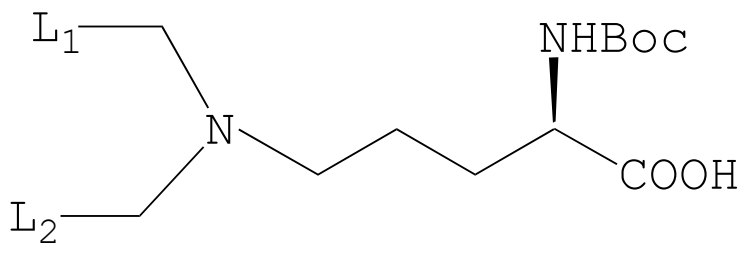

$\mathrm{L}_{1}$ or $\mathrm{L}_{2}=$
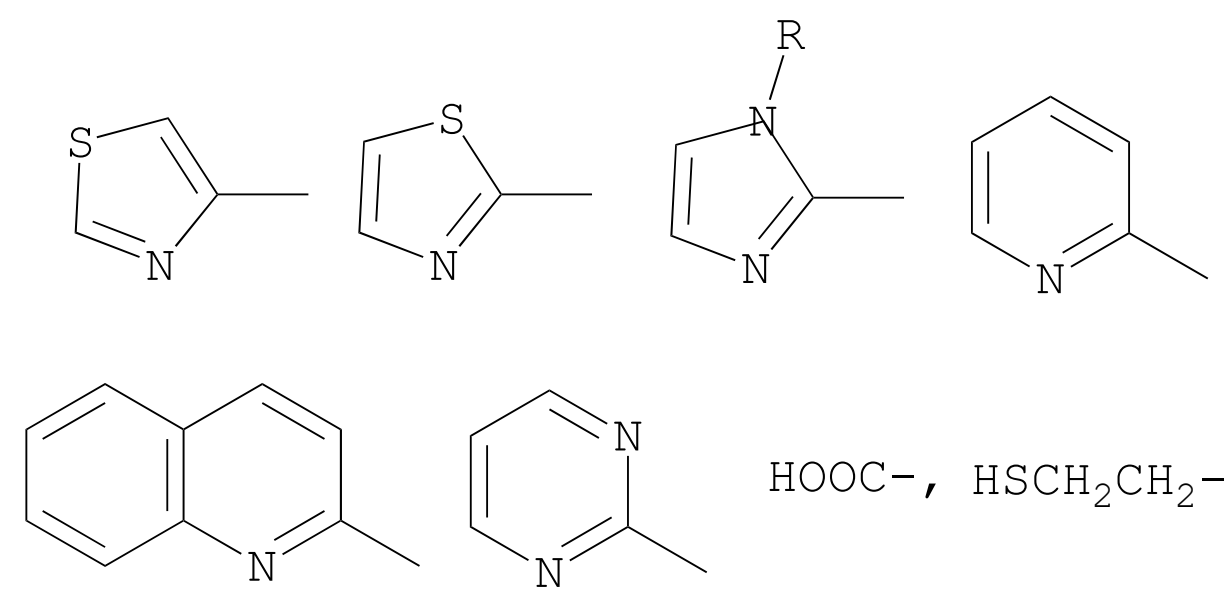

Scheme 1. Representative SAAC ligands. 
In the course of these studies, we became interested in the site-specific delivery of pharmaceuticals via the vitamin $B_{12}\left(B_{12}\right)$ uptake pathway, ${ }^{68,69}$ an observation that encouraged us to extend our imaging studies to the intrinsic factor (IF) $B_{12}$ ileum anchored receptor, cubilin, ${ }^{70,71}$ which mediates endocytotic uptake of the IF complex of $B_{12}$ to the blood. The expression of cubilin in select tissues such as placental membranes, gall bladder and the GI tract make it a potential target for selective delivery of cytotoxic or imaging agents. This transport mechanism should facilitate entry of a rhenium fluorescent probe tethered to $B_{12}$. The complex $\mathrm{B}_{12}-\mathrm{BQBA}-\mathrm{Re}(\mathrm{CO})_{3}{ }^{+}$was prepared (BQBA = tert-butyl 4-(bis- ((quinolin-2-

yl)methyl)amino)butylcarbamate), and confocal microscopy showed internalization and accumulation of the metallated bioconjugate bound to IF in the nuclear and cytosolic region of the placental BeWo cell line, confirming the key role of cubilin receptor in the internalization of $\left[\mathrm{B}_{12}-\mathrm{BQBA}-\mathrm{Re}(\mathrm{CO})_{3}{ }^{+}-\mathrm{IF}\right] .^{59}$

Despite this success, the $\mathrm{B}_{12}-\mathrm{BQBA}-\operatorname{Re}(\mathrm{CO})_{3}{ }^{+}$probe had certain deficiencies, such as water insolubility, weak fluorescence and difficulty in distinguishing probe signal from background. To overcome these difficulties, we prepared the $\mathrm{B}_{12}-\mathrm{BTBA}-\operatorname{Re}(\mathrm{CO})_{3}{ }^{+}(\mathrm{BTBA}=\mathrm{N}, \mathrm{N}-$ bis(thiazole-methyl) aminobutylamine\}), where the bisquinoline ligand was replaced by a bisthiazole ligand (Scheme 2). ${ }^{63}\left[\mathrm{~B}_{12}\right.$-BTBA-Re(CO) ${ }_{3}{ }^{+}$-IF] complex is internalized in A549 cells with clear cytoplasmic localization.

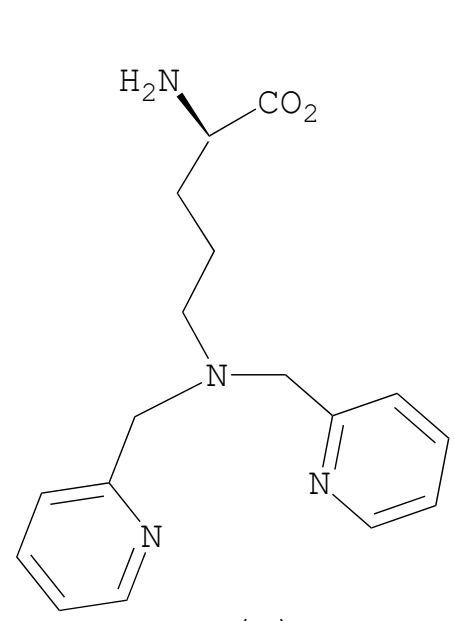

(a)

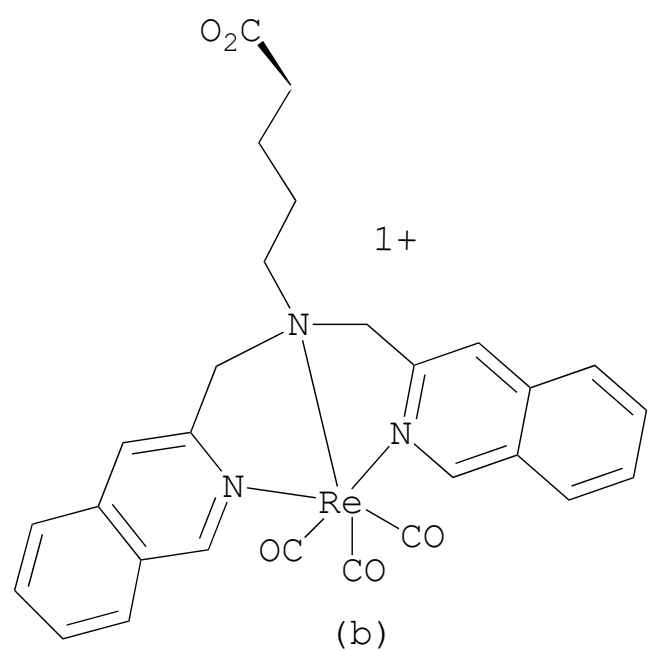

(b)

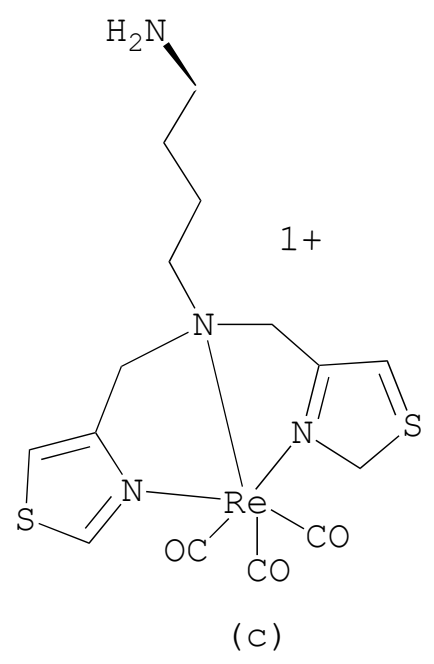

( C )

Scheme 2. (a) The prototypical SAAC ligand, N,N-bis-(2-pyridyomethyl) lysine, BPLys; (b) and (c) the fluorescent compounds $\left[\mathrm{BQPA}-\operatorname{Re}(\mathrm{CO})_{3}\right]^{+}$and $\left[\mathrm{BTBA}-\operatorname{Re}(\mathrm{CO})_{3}\right]^{+}(4-\mathrm{BT})$, respectively. 
In addition to these observations, it was noted that the probe displayed novel dual excitation/emission properties that aided in its use in cell studies through dual excitation. Detailed photophysical studies of the non-conjugated 4-BT complex alone revealed unusual behavior with emission wavelength varying with excitation wavelength far more than associated with the dual emission originally /observed exploited in the $B_{12}$ conjugate imaging work. The experimental and DFT computational studies supported the assignment of the most intense absorption bands of the electronic spectrum to ligand based $\pi-\pi^{*}$ and $d-\pi^{*}{ }^{3} \mathrm{MLCT}^{58}$ and their associated emission bands. However, it was also noted that there were also weaker bands at lower energy that gave rise to emission at lower wavelengths than those observed from excitation of the stronger bands. Since there is no observed energy transfer from the ligand based and MLCT excited species, different species must be involved. Our theoretical studies ${ }^{1}$ suggested that the emission variation with input variation observed for 4-BT is a consequence either of vibrational energy relaxation (VER) (including intramolecular vibrational energy redistribution (IVR) and vibrational cooling (VC) and/or photoinduced isomerization to a mixture of linkage isomers with discrete emission characteristics and electronic states. In any case, this represents a rare example of violation of the Kasha-Vavilov Rule (on the timescales studied) that emission occurs from the lowest energy excited state of the same multiplicity. ${ }^{72-76}$ In order to test the hypothesis that the unusual luminescence behavior of 4-BT is a consequence of isomerization to a mixture of linkage isomers, the isomeric ligands of Scheme 3 were prepared and their complexes with the $\left\{\operatorname{Re}(\mathrm{CO})_{3}\right\}^{1+}$ core investigated. The results of this study indicate that photoinduced linkage isomerization is most likely not the explanation for the unusual properties of 4-BT which appears to have unique properties. 


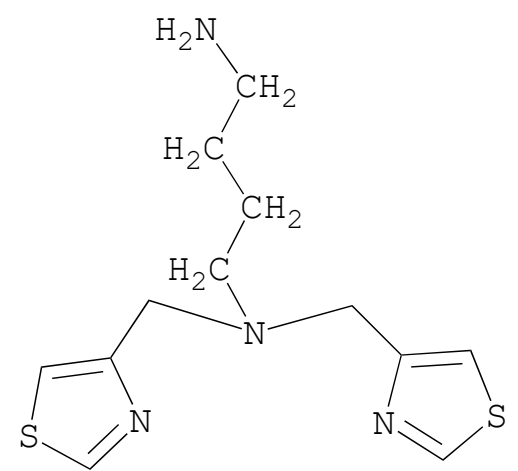

(a)

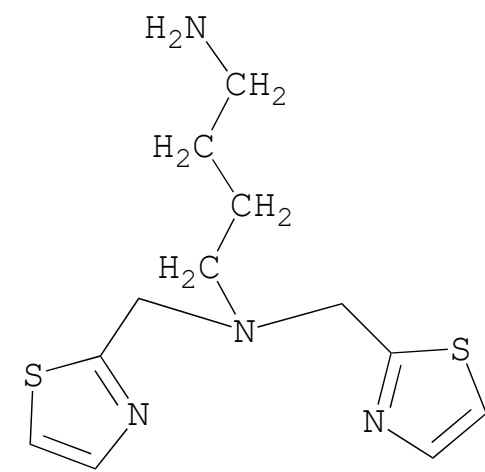

(b)

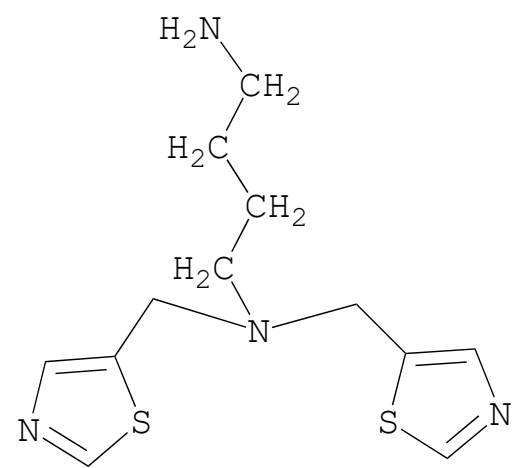

(c)

Scheme 3. The ligands of this study: (a) 4-BTBA is $\{N, N-b i s(4-t h i a z o l e-m e t h y l)$ aminobutylamine $\}$ ); $2-\mathrm{BTBA}$ is $\{\mathrm{N}, \mathrm{N}$-bis(4-thiazole-methyl) aminobutylamine $\})$; (c) 5-BTBA is $\{\mathrm{N}, \mathrm{N}$-bis(4-thiazole-methyl) aminobutylamine $\}$ ).

\section{Experimental section}

\section{Materials and Methods}

All chemicals, reagents, and solvents were purchased from Sigma-Aldrich, Combi-Blocks Inc., Acros Organic, Matrix Scientific or Fisher Scientific. Purifications were performed using an Agilent 1200 reverse-phase High-Performance Liquid Chromatography (HPLC) with an automated fraction collector and an Eclipse $C_{18}$ XBD column $(4.6 \mathrm{~mm} \times 150 \mathrm{~mm} \times 5 \mu \mathrm{m})$, or an Agilent 1100 reverse-phase HPLC using an Eclipse $C_{18}$ XBD analytical column $(4.6 \mathrm{~mm} \times 150 \mathrm{~mm} x$ $5 \mu \mathrm{m})$. All samples were purified at a flow rate of $1.0 \mathrm{~mL} \cdot \mathrm{min}^{-1}$ with a UV detection of $254 \mathrm{~nm}$. ${ }^{1} \mathrm{H}-\mathrm{NMR}$ spectroscopy was performed using a Bruker Advance DPX $400 \mathrm{MHz}$ spectrometer or a Bruker DPX 300 spectrometer. Mass spectroscopy was performed using a Shimadzu 8040 electrospray-mass spectrometer (LCMS) or a Bruker AutoFlex III Matrix Assisted Laser Desorption/Ionization-Time of Flight (MALDI-TOF) mass spectrometer. Fluorescent measurements were conducted with a PTI Quantamaster Steady State Spectrofluorimeter , while bubbling argon and oxygen, or submerged in liquid nitrogen.

\section{Syntheses}

\section{Synthesis of ligands}

The ligands were prepared using a modified procedure based on those previously described in references 1 and 40. To a stirred solution of tert-butyl (4-aminobutyl)carbamate (1.88 g, 10 
$\mathrm{mmol})$ in DCM $(100 \mathrm{~mL})$ was added the appropriate aldehyde $(22 \mathrm{mmol})$. After the mixture was stirred for $10 \mathrm{~min}, \mathrm{NaBH}(\mathrm{OAc})_{3}(22 \mathrm{mmol})$ was added and the mixture was stirred overnight at room temperature under $\mathrm{N}_{2}$. The mixture was diluted with DCM $(100 \mathrm{~mL})$ and washed with saturated sodium bicarbonate $(100 \mathrm{~mL})$, water $(2 \times 100 \mathrm{~mL})$, and brine $(100 \mathrm{~mL})$. The organic layer was dried over sodium sulfate and concentrated to afford the crude product. The crude material was purified by combiflash using EtOAc in hexane to provide tert-butyl (4-(bis(thiazol4-ylmethyl)amino)butyl)carbamate (1a) and tert-butyl (2-(bis(thiazol-4-ylmethyl)amino)butyl) carbamate (1b). Deprotection was accomplished by addition of $4 \mathrm{M} \mathrm{HCl}$ in dioxane $(5 \mathrm{~mL})$ to a solution compound 1 (a) or $1(\mathrm{~b})(2 \mathrm{mmol})$ in $\mathrm{DCM}(10 \mathrm{~mL})$ at room temperature followed by stirring for 3h. A solid was formed during the course of the reaction which was filtered, washed with DCM $(5 \mathrm{~mL})$ and used without further purification in the next step.

tert-butyl (4-(bis(thiazol-4-ylmethyl)amino)butyl)carbamate (1a): ${ }^{1} \mathrm{H} \mathrm{NMR}\left(500 \mathrm{MHz}, \mathrm{CDCl}_{3}\right) \delta$ $8.77(\mathrm{~d}, J=2.2 \mathrm{~Hz}, 2 \mathrm{H}), 7.27(\mathrm{~s}, 2 \mathrm{H}), 4.96(\mathrm{~s}, 1 \mathrm{H}), 3.88(\mathrm{~s}, 4 \mathrm{H}), 3.08(\mathrm{~d}, J=6.8 \mathrm{~Hz}, 2 \mathrm{H}), 2.55(\mathrm{t}, J=$ $7.2 \mathrm{~Hz}, 2 \mathrm{H}), 1.60(\mathrm{t}, J=7.5 \mathrm{~Hz}, 2 \mathrm{H}), 1.48(\mathrm{t}, J=7.3 \mathrm{~Hz}, 2 \mathrm{H}), 1.42(\mathrm{~s}, 9 \mathrm{H}) .{ }^{13} \mathrm{C} \mathrm{NMR}\left(126 \mathrm{MHz}, \mathrm{CDCl}_{3}\right)$ $\delta 156.08,155.37,152.52,115.83,78.93,53.43,53.30,40.27,28.51,27.71,24.50$. Yield: 56\%. 1,1-bis-4-thiazole-(1,4)-diaminobutane $\bullet \mathrm{HCl}(4-B T B A \bullet H C l):{ }^{1} \mathrm{H}$ NMR $\left(500 \mathrm{MHz}, \mathrm{CD}_{3} \mathrm{OD}\right) \delta 9.17-$ $9.08(\mathrm{~m}, 2 \mathrm{H}), 8.04-7.94(\mathrm{~m}, 2 \mathrm{H}), 4.59(\mathrm{~s}, 4 \mathrm{H}), 3.24-3.19(\mathrm{~m}, 2 \mathrm{H}), 2.96(\mathrm{t}, J=7.7 \mathrm{~Hz}, 2 \mathrm{H}), 2.04-$ $1.92(\mathrm{~m}, 2 \mathrm{H}), 1.74-1.59(\mathrm{~m}, 2 \mathrm{H}) .{ }^{13} \mathrm{C}$ NMR (126 MHz, CD $\left.3 \mathrm{OD}\right) \delta$ 157.06, 146.29, 124.85, 53.79, 51.99, 39.99, 25.54, 22.21. Yield: 90\%.

tert-butyl (4-(bis(thiazol-2-ylmethyl)amino)butyl)carbamate (1b): ${ }^{1} \mathrm{H} \mathrm{NMR}\left(500 \mathrm{MHz}, \mathrm{CDCl}_{3}\right) \delta$ $7.71(\mathrm{~d}, J=3.3 \mathrm{~Hz}, 2 \mathrm{H}), 7.30(\mathrm{~d}, J=3.3 \mathrm{~Hz}, 2 \mathrm{H}), 4.58(\mathrm{~s}, 1 \mathrm{H}), 4.06(\mathrm{~s}, 4 \mathrm{H}), 3.08(\mathrm{t}, J=6.7 \mathrm{~Hz}, 2 \mathrm{H})$, $2.65(\mathrm{t}, J=7.1 \mathrm{~Hz}, 2 \mathrm{H}), 1.64-1.56(\mathrm{~m}, 2 \mathrm{H}), 1.51(\mathrm{q}, J=7.3 \mathrm{~Hz}, 2 \mathrm{H}), 1.42(\mathrm{~s}, 9 \mathrm{H}) .{ }^{13} \mathrm{C}$ NMR $(126$ $\mathrm{MHz}_{\mathrm{CDCl}}$ ) $\delta 170.92,156.33,142.87,120.00,79.49,56.04,54.04,40.67,28.80,27.98,24.85$. Yield: 61\%.

1,1-bis-2-thiazole-(1,4)-diaminobutane •HCl (2-BTBA •HCl): ${ }^{1} \mathrm{H}$ NMR (500 MHz, CD $\left.{ }_{3} \mathrm{OD}\right) \delta 8.01$ (d, $J=3.4 \mathrm{~Hz}, 2 \mathrm{H}), 7.85(\mathrm{~d}, J=3.4 \mathrm{~Hz}, 2 \mathrm{H}), 4.83(\mathrm{~s}, 4 \mathrm{H}), 3.32-3.29(\mathrm{~m}, 2 \mathrm{H}), 2.97(\mathrm{t}, J=7.7 \mathrm{~Hz}, 2 \mathrm{H})$, 1.94 (ddd, $J=10.9,6.3,2.8 \mathrm{~Hz}, 2 \mathrm{H}), 1.72$ (q, $J=7.9 \mathrm{~Hz}, 2 \mathrm{H}) .{ }^{13} \mathrm{C}$ NMR $\left(126 \mathrm{MHz}, \mathrm{CD}_{3} \mathrm{OD}\right) \delta 142.94$, 124.37, 54.98, 53.44, 40.12, 25.66, 23.00. Yield: 92\%. 
tert-butyl (4-(bis(thiazol-5-y/methyl)amino)butyl)carbamate (1c): ${ }^{1} \mathrm{H} \mathrm{NMR}\left(500 \mathrm{MHz}, \mathrm{CDCl}_{3}\right) \delta$ $8.76(\mathrm{~s}, 2 \mathrm{H}), 7.71(\mathrm{~s}, 2 \mathrm{H}), 4.55(\mathrm{~s}, 1 \mathrm{H}), 3.83(\mathrm{~s}, 4 \mathrm{H}), 3.09(\mathrm{~d}, J=6.8 \mathrm{~Hz}, 2 \mathrm{H}), 2.51(\mathrm{~s}, 2 \mathrm{H}), 1.61-$ $1.51(\mathrm{~m}, 2 \mathrm{H}), 1.50-1.45(\mathrm{~m}, 2 \mathrm{H}), 1.43(\mathrm{~s}, 9 \mathrm{H}) .{ }^{13} \mathrm{C} \mathrm{NMR}\left(126 \mathrm{MHz}, \mathrm{CDCl}_{3}\right) \delta$ 156.10, 153.61, 153.57, 141.84, 136.93, 79.28, 52.69, 49.24, 40.44, 28.55, 27.86, 24.48.MS (ESI+): $\mathrm{m} / \mathrm{z}$ calcd for $\mathrm{C}_{17} \mathrm{H}_{26} \mathrm{~N}_{4} \mathrm{~S}_{2} \mathrm{O}_{2}[\mathrm{M}+\mathrm{H}]$, found 283.5 .

1,1-bis-5-thiazolemethyl-(1,4)-diaminobutane $\bullet H C l(5-B T B A \bullet H C l): ~{ }^{1} \mathrm{H} \mathrm{NMR}\left(500 \mathrm{MHz}, \mathrm{CD}_{3} \mathrm{OD}\right) \delta$ $9.79(\mathrm{~s}, 2 \mathrm{H}), 8.49(\mathrm{~s}, 2 \mathrm{H}), 4.78(\mathrm{~s}, 4 \mathrm{H}), 3.17(\mathrm{~d}, J=8.7 \mathrm{~Hz}, 2 \mathrm{H}), 3.01(\mathrm{t}, J=7.6 \mathrm{~Hz}, 2 \mathrm{H}), 1.96(\mathrm{td}, J=$ 7.3, 6.2, $3.4 \mathrm{~Hz}, 2 \mathrm{H}), 1.73(\mathrm{t}, J=7.8 \mathrm{~Hz}, 2 \mathrm{H}) .{ }^{13} \mathrm{C} \mathrm{NMR}(126 \mathrm{MHz}$, DMSO-d 6 ) $\delta 158.12,147.15$, 126.15, 49.81, 46.80, 38.05, 24.18, 20.16. MS (ESI+): $\mathrm{m} / \mathrm{z}$ calcd for $\mathrm{C}_{12} \mathrm{H}_{18} \mathrm{~N}_{4} \mathrm{~S}_{2}[\mathrm{M}+2 \mathrm{H}]^{+}, 384.6$; found 384.5 .

Synthesis $\left[\operatorname{Re}\left(\mathrm{H}_{2} \mathrm{O}\right)_{3}(\mathrm{CO})_{3}\right] \mathrm{Br}$

$\left[\operatorname{Re}(\mathrm{CO})_{5}\right] \mathrm{Br}$ was purchased from Sigma-Aldrich and used without further purification. $\left[\operatorname{Re}(\mathrm{CO})_{5}\right] \mathrm{Br} 10 \mathrm{~g}, 0.03 \mathrm{~mol}$ ) was placed in a $250 \mathrm{~mL}$ round-bottom flask, distilled $\mathrm{H}_{2} \mathrm{O}(100 \mathrm{ml})$ added and the reaction heated to reflux for $24 \mathrm{~h}$. Periodic rinsing of the reflux condenser washed unreacted $\left[\operatorname{Re}(\mathrm{CO})_{5}\right] \mathrm{Br}$ from the condenser into the reaction solution. The crude mixture was cooled to room temperature and filtered through a plug of Celite to remove small amounts of particulate impurities. Subsequently, the solution was concentrated under vacuum to give the desired product as a light green powder in nearly quantitative yield. IR ( $\mathrm{MeOH}$, $\left.\mathrm{cm}^{-1}\right): 2025,1941\left(\mathrm{v}(\mathrm{C}=\mathrm{O}) \text { for } \text { fac } \mathrm{Re}(\mathrm{CO})_{3}\right\}^{+1}$ group). MS $\left(\mathrm{ESI}^{+}\right): \mathrm{m} / z$ calcd for $\mathrm{C}_{3} \mathrm{H}_{6} \mathrm{O}_{6} \mathrm{Re}[\mathrm{M}-\mathrm{Br}]$ 321.3 , found 321.2 .

General procedure for the syntheses of Re complexes

Equimolar concentrations of $\left[\mathrm{Re}\left(\mathrm{H}_{2} \mathrm{O}\right)_{3}(\mathrm{CO})_{3}\right] \mathrm{Br}$ and the selected ligand analogue were refluxed in methanol at $65^{\circ} \mathrm{C}$ for 3 hours. Final products were allowed to cool and concentrated under vacuum. The crude products were dissolved in pure water and purified via HPLC. Gradients started at $95 \% 0.1 \%$ TFA in $\mathrm{H}_{2} \mathrm{O}$ (Solvent A), 5\% methanol (Solvent B). The gradient was held at $5 \%$ Solvent B for 2 min and increased to $40 \%$ Solvent B over 1 min where it was held at $40 \%$ for 8 minutes. 
Representative Synthesis of [Re(CO) 3 -1,1-bisthiazole-(1,4)-diaminobutane)] bromide (4-BT) $\operatorname{Re}(\mathrm{CO})_{3}\left(\mathrm{H}_{2} \mathrm{O}\right)_{3} \mathrm{Br}(420 \mathrm{mg}, 1.04 \mathrm{mmol}$ ), and 1,1-bisthiazole-1,4-diaminobutane (294 mg, 1.04 mmol) were refluxed in $\mathrm{MeOH}$ at $>65^{\circ} \mathrm{C}$ for $3 \mathrm{~h}$. The solvent was reduced under vacuum and dissolved in $10 \% \mathrm{MeOH}, 10 \%$ dimethyl sulfoxide (DMSO) ( $\mathrm{v} / \mathrm{v}$ ) in $\mathrm{H}_{2} \mathrm{O}$. 4-BT was purified by reverse-phase HPLC with a gradient of 95\% $0.1 \%$ TFA in $\mathrm{H} 2 \mathrm{O}$ and 5\% MeCN increased to $12 \%$ MeCN over $7 \mathrm{~min}$, then increased to $20 \% \mathrm{MeCN}$ over $2 \mathrm{~min}$, and finally increased to $25 \% \mathrm{MeCN}$ over 5 minutes. The complex was characterized using MALDI-ToF MS (Shimadzu LCMS-4080) using a $10 \mathrm{mg} / \mathrm{mL}$ alpha-cyano-4-hydroxycinnamic acid (CHCA) matrix, dissolved in 50:50 mixture of $\mathrm{H}_{2} \mathrm{O}: \mathrm{MeCN}$ with $0.1 \%$ formic acid; 4-BT was also characterized using ${ }^{1} \mathrm{H}-\mathrm{NMR}$ in DMSO- $\mathrm{d}_{6}$. Further characterization was done by EAS and fluorescence spectroscopy. Yield is $5 \%$ at $>99+\%$ purity based on HPLC. ${ }^{1} \mathrm{H}-\mathrm{NMR}(500 \mathrm{MHz}) \mathrm{D}_{2} \mathrm{O}: \delta=10.43(\mathrm{~d}, 2 \mathrm{H}), \delta=8.61(\mathrm{~s}, 2 \mathrm{H}), \delta=$ $5.50(\mathrm{~m}, 4 \mathrm{H}), \delta=3.82(\mathrm{t}, 2 \mathrm{H}), \delta=3.51(\mathrm{t}, 2 \mathrm{H}), \delta=2.82(\mathrm{~d}, 2 \mathrm{H}), \delta=2.57(\mathrm{t}, 2 \mathrm{H})$. HRMS (ESI+), calc for $\mathrm{C}_{15} \mathrm{H}_{18} \mathrm{~N}_{4} \mathrm{O}_{3} \mathrm{~S}_{2} \mathrm{Re} 552.66$, found 552.66. HPLC (UV, $254 \mathrm{~nm}$ ): $\mathrm{R}_{\mathrm{t}}=5.2 \mathrm{~min}$.

Crystals of $\left[\operatorname{Re}(\mathrm{CO})_{3}\right.$-1,1-bis-2-thiazolemethyl-1-aminobutylammonium)] bromide ohydrobromide (2-BT•HBr) for $x$-ray diffraction were grown by dissolving $50 \mathrm{mg}$ of the complex in $5 \mathrm{~mL}$ of hot methanol in a flask equipped with a reflux condenser. The temperature was slowly lowered from $64{ }^{\circ} \mathrm{C}$ to room temperature over a period of $4 \mathrm{~h}$, whereupon blocks of 2-BT•HBr were observed to crystallize from solution.

$\left[\operatorname{Re}(\mathrm{CO})_{3}\right.$-1,1-bis-2-thiazolemethyl-(1,4)-diaminobutane)] bromide (2-BT): ${ }^{1} \mathrm{H}-\mathrm{NMR}(400 \mathrm{MHz})$ $\mathrm{D}_{2} \mathrm{O}: \delta=7.82(\mathrm{~d}, 2 \mathrm{H}), \delta=7.61(\mathrm{~d}, 2 \mathrm{H}), \delta=4.96(\mathrm{t}, 4 \mathrm{H}), \delta=3.96(\mathrm{t}, 2 \mathrm{H}), \delta=3.12(\mathrm{t}, 2 \mathrm{H}), \delta=1.98$ $(\mathrm{m}, 2 \mathrm{H}), \delta=1.78(\mathrm{~m}, 2 \mathrm{H})$. HRMS (ESI+), calc for $\mathrm{C}_{15} \mathrm{H}_{18} \mathrm{~N}_{4} \mathrm{O}_{3} \mathrm{~S}_{2} \mathrm{Re} 552.66$, found 552.66. HPLC $(U V, 254 \mathrm{~nm}): R_{t}=4.7 \mathrm{~min}$. Crystals were grown by slow evaporation from methanol. Attempted synthesis of $\left[\operatorname{Re}(\mathrm{CO})_{3}-1,1-\right.$ bis-5-thiazolemethyl-(1,4)-diaminobutane)] bromide (5-BT): Several attempts were made to prepare this isomer: (1) refluxing the ligand with $\operatorname{Re}(\mathrm{CO})_{3}\left(\mathrm{H}_{2} \mathrm{O}\right)_{3} \mathrm{Br}$ in methanol for up to $48 \mathrm{~h}$, (2) refluxing the ligand with $\operatorname{Re}(\mathrm{CO})_{3}\left(\mathrm{H}_{2} \mathrm{O}\right)_{3} \mathrm{Br}$ in various solvents including acetonitrile, DMF and water/ethanol mixtures for 6, 24 and 48h, (3) refluxing the ligand with $\operatorname{Re}(\mathrm{CO})_{5} \mathrm{Br}$ in the solvents noted above for several time periods, and (4) solvatothermal syntheses in acetonitrile at $100{ }^{\circ} \mathrm{C}$ for 24 to $72 \mathrm{~h}$. These attempts invariably yielded the unreacted starting materials. 
Attempted Synthesis of [Re(CO) $)_{3}-1,1$-bis-5-thiazolemethyl-(1,4)-diaminobutane] bromide (5-BT).

(a) The procedure adopted for the preparation of 4-BT was used. The starting unreacted materials were recovered after 3 to $24 \mathrm{~h}$ of reflux. (b) Syntheses in ethanol, DMF and acetonitrile were also unsuccessful. (c) Solvatothermal synthesis in various water/acetonitrile mixtures failed to produce the ligand bound product.

\section{Air, Argon, Oxygen atmosphere Spectroscopic Measurements}

4-BT was dissolved in EPA (ethanol:isopentane:ethyl ether 2:5:5) emission profiles were collected in an air atmosphere originally with excitation at 280 and $488 \mathrm{~nm}$. Argon was then bubbled through the solution for 15 minutes and emission scans were recollected. Oxygen was then bubbled through the solution for 15 minutes and emission scans were recollected.

\section{K Spectroscopic Measurements}

4-BT was dissolved in EPA and placed in a specially made cuvette submerged in liquid nitrogen. Excitation scans were performed at 400, 450, 470, 490, and $500 \mathrm{~nm}$. Emission scans were performed at $315 \mathrm{~nm}$.

2-BT was dissolved in EPA and placed in a specially made cuvette submerged in liquid nitrogen. Emission scans were performed with excitation at 240, 250, 260, and $270 \mathrm{~nm}$.

\section{Solid state fluorescent measurements}

A solution of the sample is prepared by adding $<0.5 \mathrm{ml}$ of solvent (DCM or MeCN, depending on solubility) and agitating until the sample dissolves. Subsequently, a drop of this solution is introduced into a cuvette with a narrow aperture for a stopper, which is laid on its side and slowly tilted until the solution has covered the bottom face of the cuvette as it lies. A gentle stream of nitrogen is played over the solution through a flexible tube until it has evaporated. This procedure is repeated until these is a visible film on the glass, which is then place in the spectrometer with the cuvette holder rotated so that the face of the cuvette with the film is angled to face both the excitation slits and the detection slits (but not at 45 degrees to directly reflect the excitation beam into the detector). 
X-Ray Crystallography.

Only low quality crystals of the Re complexes could be grown, despite numerous attempts in a variety of solvents (methanol, DMF, acetonitrile, methylene chloride) and solvent mixtures under different conditions of temperature and concentration. In all instances, the crystals proved to be twinned. Crystallographic data for 2-BT•HBr were collected on a Bruker KAPPA APEX DUO diffractometer using Mo- $K_{\alpha}$ radiation $(\lambda=0.71073 \AA ̊)$ containing an APEX II CCD system. ${ }^{77}$ All data collections were taken at low temperature (90K). The data were corrected for Lorentz and polarization effects, ${ }^{78}$ and adsorption corrections were made using SADABS. ${ }^{79}$ The structure was solved by direct methods. Refinements for each structure were carried out using the SHELXTL crystallographic software. ${ }^{80}$ Following assigning all non-hydrogen atoms, the models were refined against $F^{2}$ first using isotropic and then using anisotropic thermal displacement parameters. The hydrogen atoms were introduced in calculated positions and then refined isotropically. Neutral atom scattering coefficients along with anomalous dispersion corrections were taken from the International Tables, Vol. C. Images of the crystal structures were generated using CrystalMaker ${ }^{\circledR}{ }^{81}$ Full tables of bond lengths and angles for the structures are given in the Supplementary materials. Summary of crystallographic details for the structure of 2-BT•HBr: $\mathrm{C}_{15} \mathrm{H}_{19} \mathrm{Br}_{2} \mathrm{~N}_{4} \mathrm{O}_{3} \mathrm{~S}_{2} \mathrm{Re}, \mathrm{fw}=713.48$, orthorhombic Pnnm, a = 27.550(3) $\AA, b=8.479(1) \AA, c=12.52591) \AA, V=2925.6(1) \AA^{3}, Z=4, \mu=7.04 \mathrm{~mm}^{-1}$, Dcalc $=1.620 \mathrm{~g} \mathrm{~cm}^{-1}$, $R 1=0.1048, w R 2=0.3128$ for 1377 reflections with $F_{o}>4 \sigma\left(F_{0}\right)$. CCDC contains the supplementary crystallographic data for the structures of 2-BT•HBr. These data can be obtained free of charge via http://www.ccdc.cam.ac.uk/conts/retrieving.html, or from the Cambridge Crystallographic Data Centre, 12 Union Road, Cambridge CB2 1EZ, UK; fax: (+44) 1223-336-033; or e-mail: deposit@ccdc.cam.ac.uk.

\section{Results and Discussion}

Syntheses and Structures of Compounds

The ligands were prepared in good yield according to a modified version of previously reported syntheses ${ }^{1,40}$ as summarized in Scheme 4. 


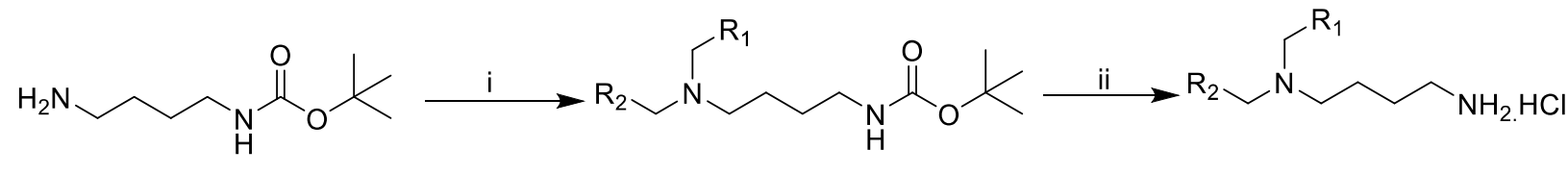

$1(a, b)$

2-BT, 4-BT

i) R-CHO, $\mathrm{NaBH}(\mathrm{OAC})_{3}, \mathrm{DCM}$, r.t, 12h ii) $4 \mathrm{M}$ Dioxane-HCl, r.t, $3 \mathrm{~h}$

Scheme 4. Synthesis of ligands.

The complexes 2-BT and 4-BT were prepared by reaction of the appropriate ligand with $\operatorname{Re}(\mathrm{CO})_{3}\left(\mathrm{H}_{2} \mathrm{O}\right)_{3} \mathrm{Br}$ in methanol. 2_BT was crystallized by slow evaporation from methanol solution. However, 2-BT could only be crystallized by slowly ramping down the temperature of a methanol solution from the boiling point to room temperature. The crystalline material was subsequently shown to be the hydrobromide salt 2-BT•HBr. Despite repeated attempts, even under forcing solvatothermal conditions, the complex incorporating the 1,1-bis-5-thiazole-(1,4)diaminobutane ligand, i.e., $\left[\operatorname{Re}(\mathrm{CO})_{3}\right.$-1,1-bis-5-thiazolemethyl-(1,4)-diaminobutane)] $\mathrm{Br}(5-\mathrm{BT})$, could not be prepared. This observation is consistent with the extensive literature on the coordination chemistry of thiazole ligands with transition metals which provides no examples of coordination through the sulfur.

As shown in Figure 1, the $\mathrm{x}$-ray structural studies confirm that 2-BT•HBr exhibits the chemically robust $\mathrm{fac}_{-}\left\{\operatorname{Re}(\mathrm{CO})_{3}\right\}^{+}$core and distorted octahedral geometries with the remaining coordination sites occupied by the amine nitrogen donor and the nitrogen atoms of the thiazole ligands. No evidence for sulfur coordination is observed as anticipated from previous studies. ${ }^{35,82-86}$ The Re-carbonyl distances, Re-C of 1.948(32) $\AA$, are consistent with those described for similar complexes. ${ }^{35,87}$ The Re-amine distance of $2.348(27) \AA$, is somewhat longer than the Re-thiazole nitrogen distances of 2.099(22) $\AA$, consistent with $\mathrm{sp}^{3}$ and $\mathrm{sp}^{2}$ hybridization, respectively. The most significant distortions from idealized octahedral geometries are the amine nitrogen-Re-thiazole nitrogen angles which result from the formation of strained five-membered chelate rings. The cation of the crystal structure is present as the +2 species $\left[\operatorname{Re}(\mathrm{CO})_{3}\left\{\left(\mathrm{C}_{3} \mathrm{H}_{2} \mathrm{SNCH}_{2}\right)_{2} \mathrm{~N}\left(\mathrm{CH}_{2}\right)_{4} \mathrm{NH}_{3}\right\}\right]^{+2}$ as a consequence of protonation of the amine 
terminus of the ligand. Charge compensation for the di-cationic $\left[\operatorname{Re}(\mathrm{CO})_{3}\left\{\left(\mathrm{C}_{3} \mathrm{H}_{2} \mathrm{SNCH}_{2}\right)_{2} \mathrm{~N}\left(\mathrm{CH}_{2}\right)_{4} \mathrm{NH}_{3}\right\}\right]^{+2}$ is provided by two uncoordinated $\mathrm{Br}$ - anions (see Supplementary materials Figure $\mathrm{S}$ ).

\section{Spectroscopic Studies}

In our previous study, we also reported that the $\operatorname{Re}(\mathrm{CO})_{3}$-1,1-bis-4-thiazole-(1,4)-

diaminobutane complex $\left[\mathrm{Re}(\mathrm{CO})_{3}\left\{\left(\mathrm{C}_{3} \mathrm{H}_{2} \mathrm{NSCH}_{2}\right)_{2} \mathrm{~N}\left(\mathrm{CH}_{2}\right)_{4} \mathrm{NH}_{2}\right\}\right]^{+}$(4-BT) exhibited variability of the emission maximum with excitation wavelength (see Supplementary Figure S1) with a marked, and non-linear, red shift of the emission maximum associated with the progressive lengthening of excitation wavelength. This behavior persisted in different solvents, showing changes in the emission maximum with excitation wavelength, which were generally red- shifted, as expected as a more polar solvent stabilized the more polar excited states associated especially with charge-separated species. Furthermore, the emission maxima were found to shift at different rates as a function of the excitation wavelengths, as shown by the slope of the curve in a plot of maximum emission wavelength as a function of excitation wavelength (Figure 1).

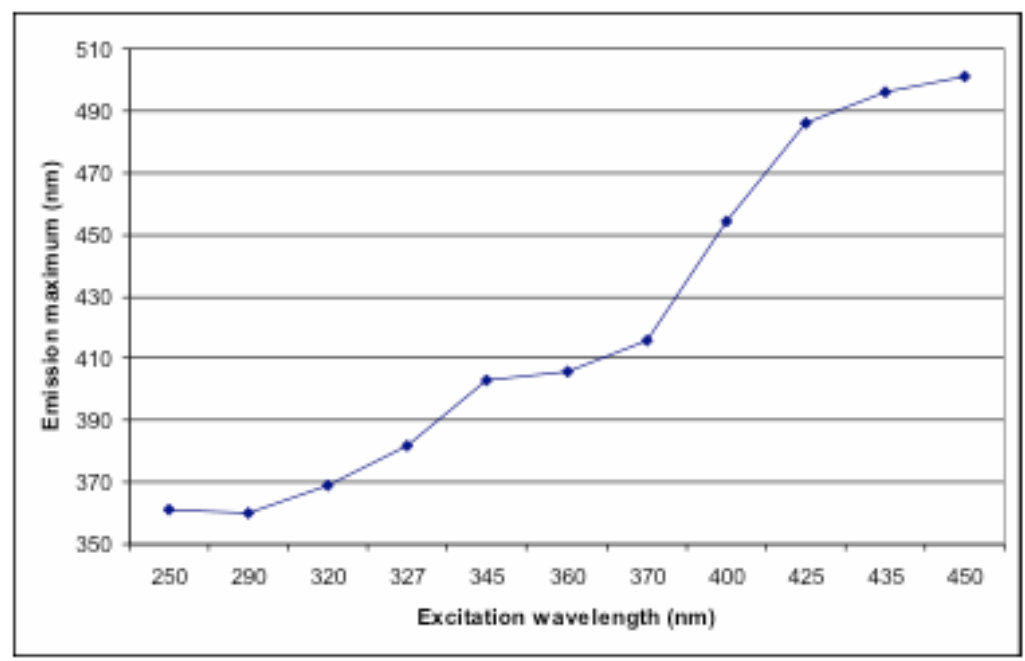

Figure 1. Variation of emission maximum of 4-BT with excitation wavelength in $\mathrm{MeOH}$.

Both experimental and computational studies support the assignment of the most intense absorption bands observed in the electronic absorption spectra as being of ligandbased $\pi-\pi^{*}$ and $d-\pi^{*}{ }^{1}$ MLCT nature, and their associated emission bands. However, there 
were weaker broad absorption bands at lower energy, which give rise to emission at lower wavelengths than those observed from excitation of the normal bands. The lack of observed energy transfer from the ligand based and MLCT excited species to the lower energy emissions implies different species are involved. The preliminary theoretical studies suggested that photo-isomerisation of 4-BT to a mixture of coordination isomers with discrete emission characteristics and electronic structures gave rise to the observed emission characteristics. This speculation would require the existence of N,S- and/or S,S-isomers of the 4-BT complex (Scheme 5). To investigate this possibility, several studies, focusing on structural, DFT, solution and solid-state photophysics, were undertaken. 


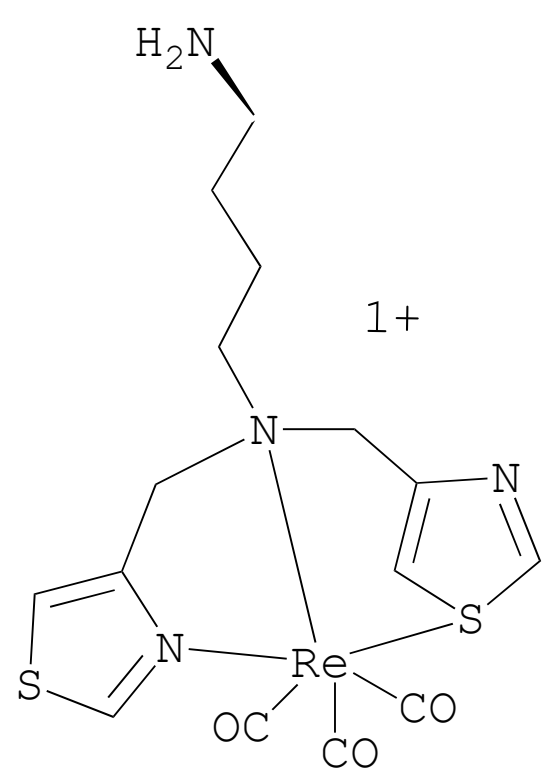

(a)

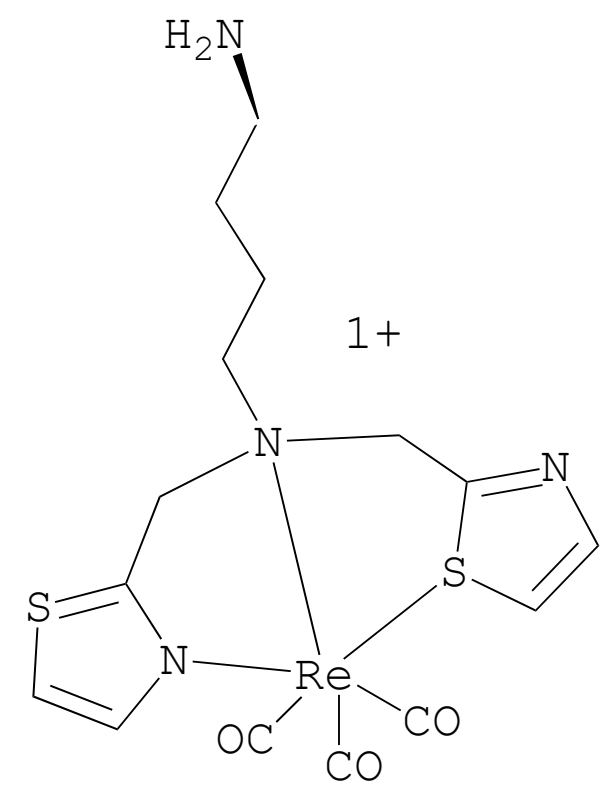

(c)

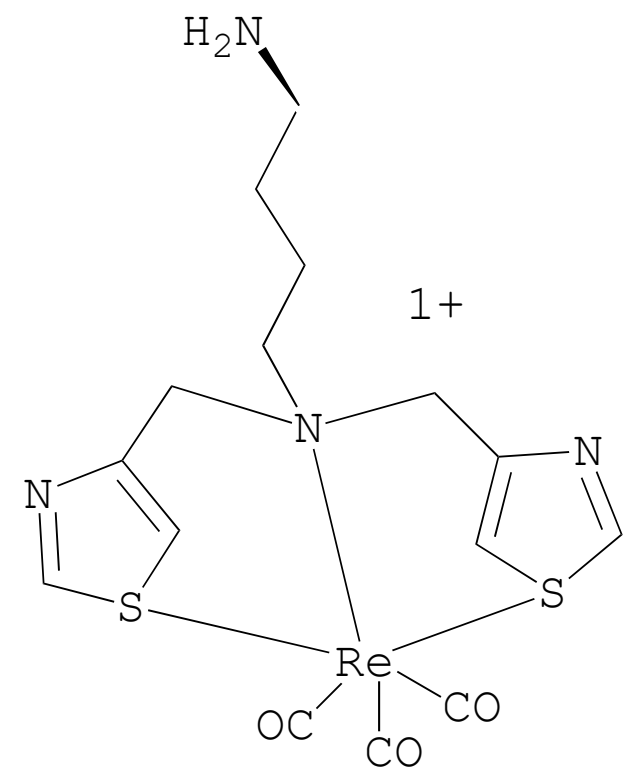

(b)

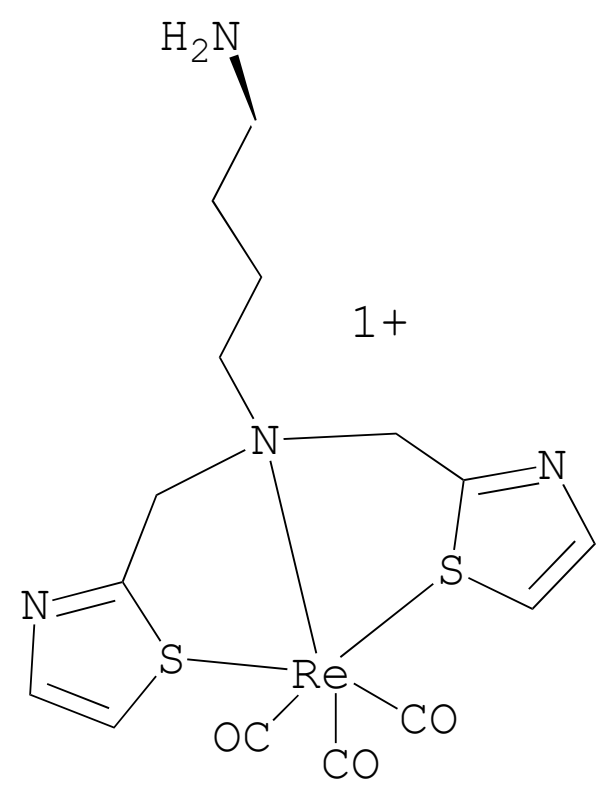

(d)

Scheme 5. (a) N,S-isomer of 4-BT; (b) S,S-isomer of 4-BT; (c) N,S-isomer of 2-BT: (d) S,S-isomer of 2-BT. 
Low temperature studies (77 K) on 2-BT and 4-BT

Spectroscopic studies were performed on 4-BT and 2-BT at 77K in liquid nitrogen. Upon excitation at $315 \mathrm{~nm}$ at $77 \mathrm{~K}$, the single emission band observed at room temperature for 4-BT now exhibits multiple emission bands (Figure 3, inset). Excitation scans of 4-BT were conducted at $400,450,470,490$, and $500 \mathrm{~nm}$ at $77 \mathrm{~K}$. The excitation scans of 4-BT at $400 \mathrm{~nm}$ shows major contributions from approximately $300 \mathrm{~nm}$, and as the excitation increases the contributions from approximately 250 and $300 \mathrm{~nm}$ are inversely proportional, suggesting that there are multiple emissive states accessible to the complex. Emission profiles for 2-BT (Figure 4) at both room temperature and 77K show no difference in profile or number of emissive bands, an observation consistent with Kasha's rule. Thus, the behavior of 2-BT is quite different from that observed for 4-BT, suggesting that the unusual luminescence characteristics of 4-BT are unique to that isomer.

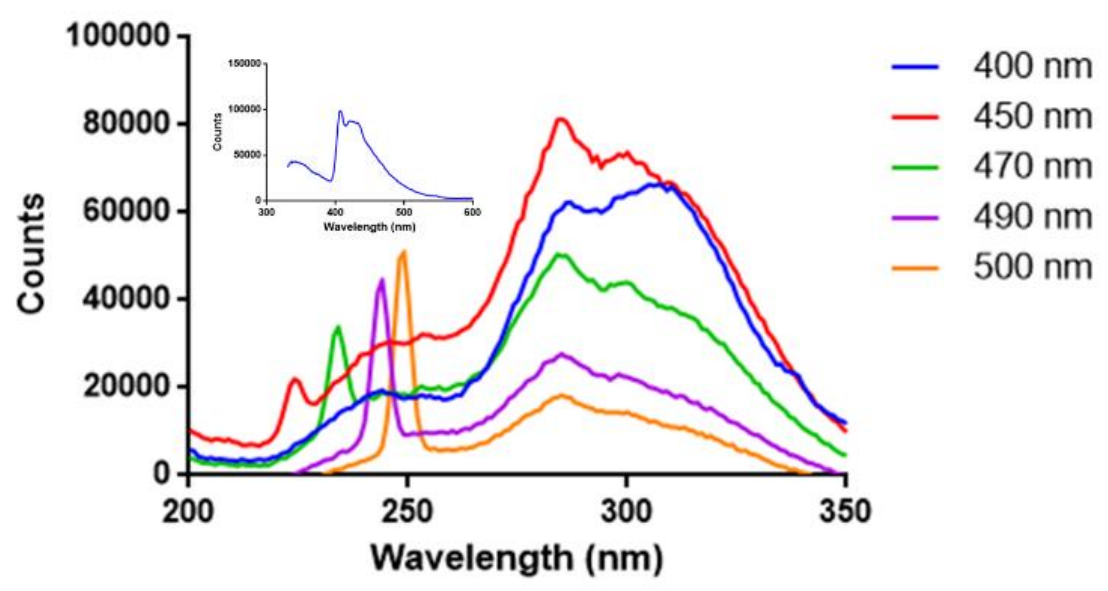

Figure 3. Excitation scans for 4-BT at 77K in EPA. Inset: emission scan with excitation at $315 \mathrm{~nm}$ at $77 \mathrm{~K}$, solvent: EPA. 

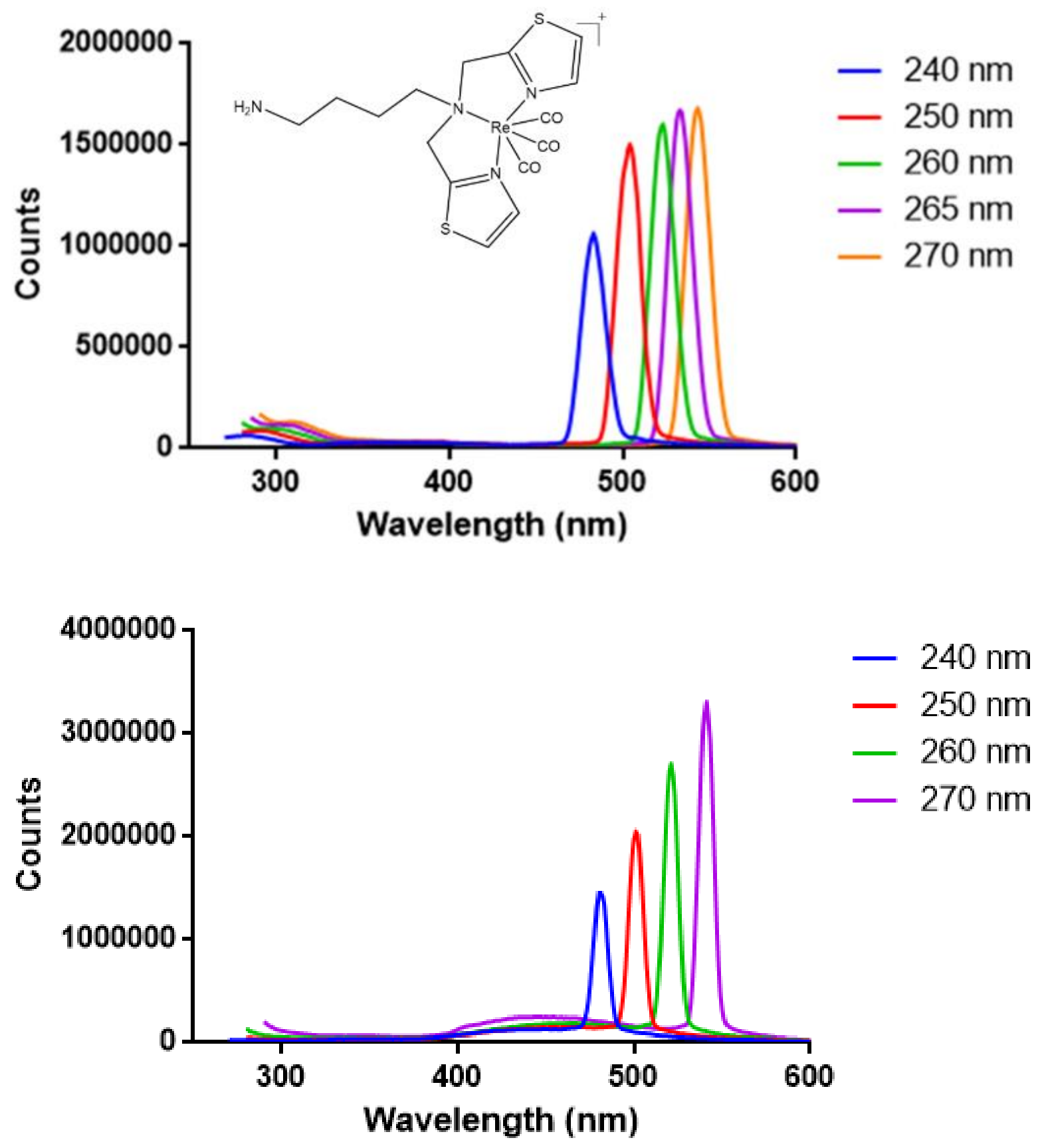

Figure 4. Top: Emission scan for 2-BT at room temperature in EPA. Bottom: Emission scans for 2-BT at 77K in EPA. 
Investigation of triplet state in Air, $\mathrm{O}_{2}$ or inert atmosphere (Argon)

Characterization of a triplet state can be accomplished by changing the amount of gas present in the solvent. Oxygen is a known triplet state quencher and will decrease emission when introduced to a solution containing the complex of interest. Emission profiles of 4-BT, where a triplet state is anticipated for excitation at $488 \mathrm{~nm}$, were collected under ambient conditions, prior to introducing argon or oxygen and subsequently after introducing argon and oxygen. The emission profile at this wavelength remains unchanged, suggesting that the emission does not arise from a triplet state (Figure 5). The same experiments were conducted with excitation at $280 \mathrm{~nm}$ (Figure 6), which clearly demonstrate decrease in emission under $\mathrm{O}_{2}$ and an increase in emission under Ar. These observations are consistent with 4-BT accessing a triplet state upon excitation at $280 \mathrm{~nm}$, rather than the expected singlet state, possibly arising from the ligand (see DFT studies, vide infra). However, excitation at $488 \mathrm{~nm}$ does not result in a triplet state.

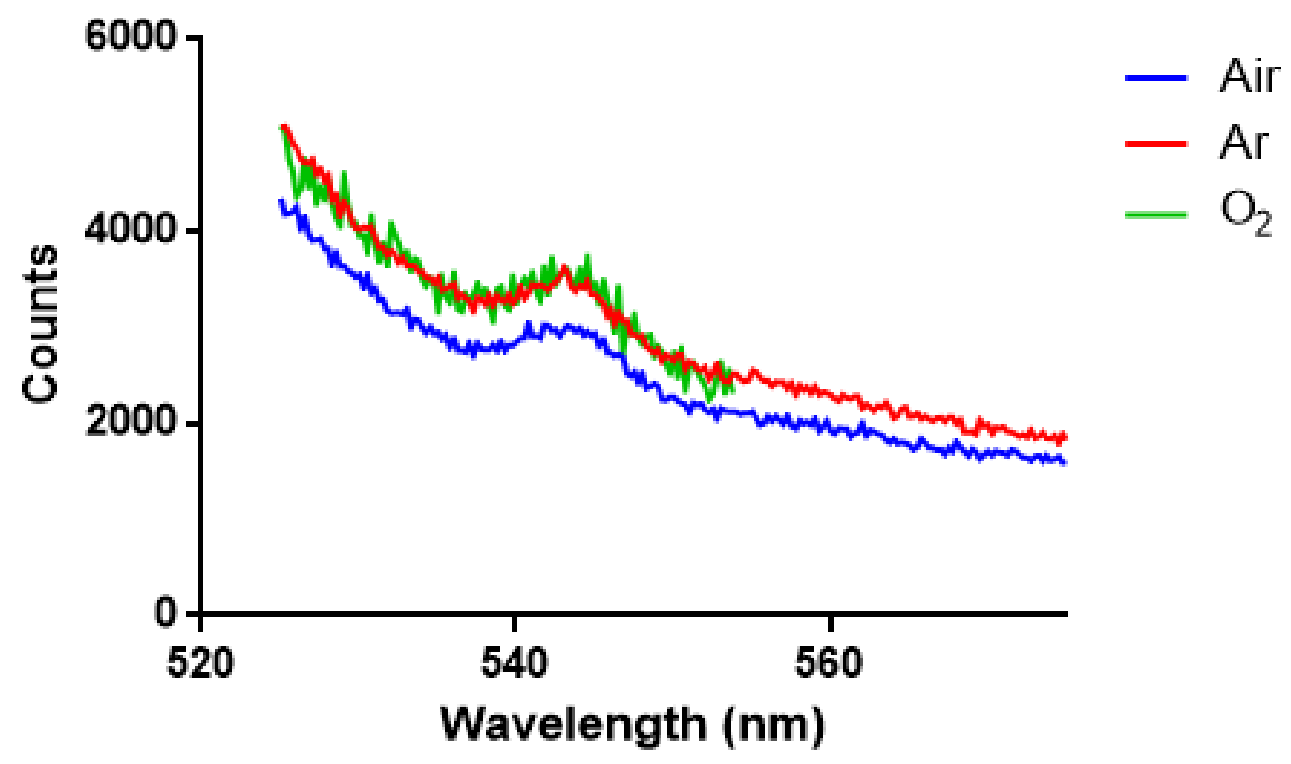

Figure 5. Emission scan for 4-BT at room temperature under air (blue), argon (red) and oxygen atmospheres (green) at $488 \mathrm{~nm}$ in EPA. 


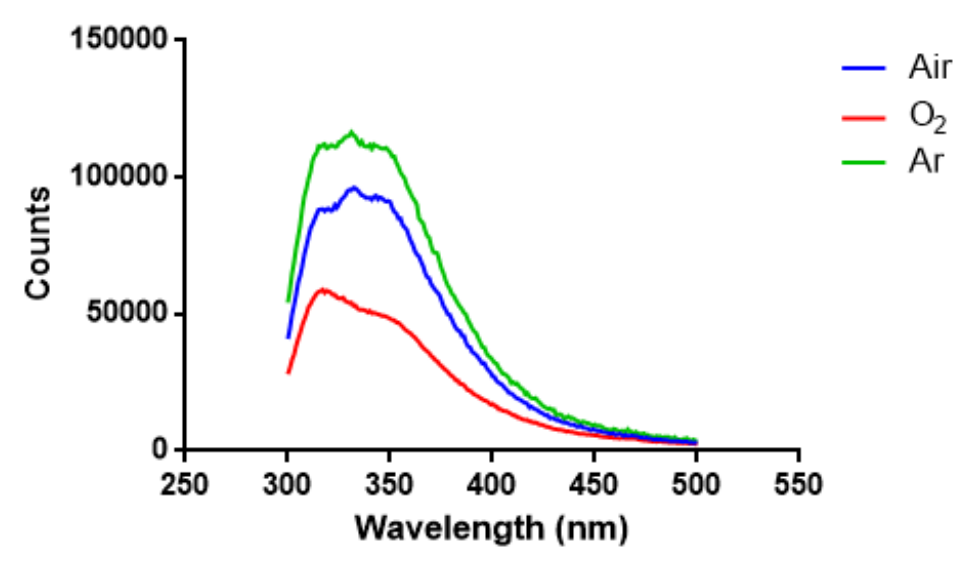

Figure 6: Emission scan for 4-BT at room temperature under air (blue), argon (green) and oxygen atmospheres (red) at $280 \mathrm{~nm}$ in EPA.

\section{Solid State Studies}

In the 3D fluorescence spectroscopy experiments the relative emission intensity of the give code number was recorded between 400 and $500 \mathrm{~nm}$ for a series of excitation wavelengths from 310 to $360 \mathrm{~nm}$ in $5 \mathrm{~nm}$ increments. The relative emission intensities are presented in two formats, in Figure 7 as a pseudo 3D topographical image, and in Figure 8 as a 2D grid of excitation vs. emission wavelength with a coloured contour presentation of the emission intensity. A sample which shows a single emission maximum and a single excitation maximum will appear to have a single summit in Figure 7 and one high intensity feature highlighted by the coloured contours in Figure 8, which is clearly not the case. Close examination of Figure 8 shows that while the most intense emission is always around $450-500 \mathrm{~nm}$ this appears to be originating from two different excitation mechanisms (i.e. electronic transitions), one with maximum efficiency around $315 \mathrm{~nm}$ and one with maximum efficiency around $335 \mathrm{~nm}$, with a minimum around $325 \mathrm{~nm}$ seen as a valley between the two peaks. These features may also arise from different emission mechanisms. Additionally, there is an additional feature with maximum emission intensity around $450 \mathrm{~nm}$, which is most efficiently excited around $330 \mathrm{~nm}$, and barely at all at $315 \mathrm{~nm}$, clearly showing it is of different origin to the $450-500 \mathrm{~nm}$ emission bands. Thus Figures 7 and 8 clearly illustrate that the sample is displaying a range of different emission behaviours, dependent upon the excitation wavelength, which is best interpreted in 
terms of a failure for all of the excited states to relax to a single emissive state regardless of excitation wavelength, as would be predicted by Kasha's rule.

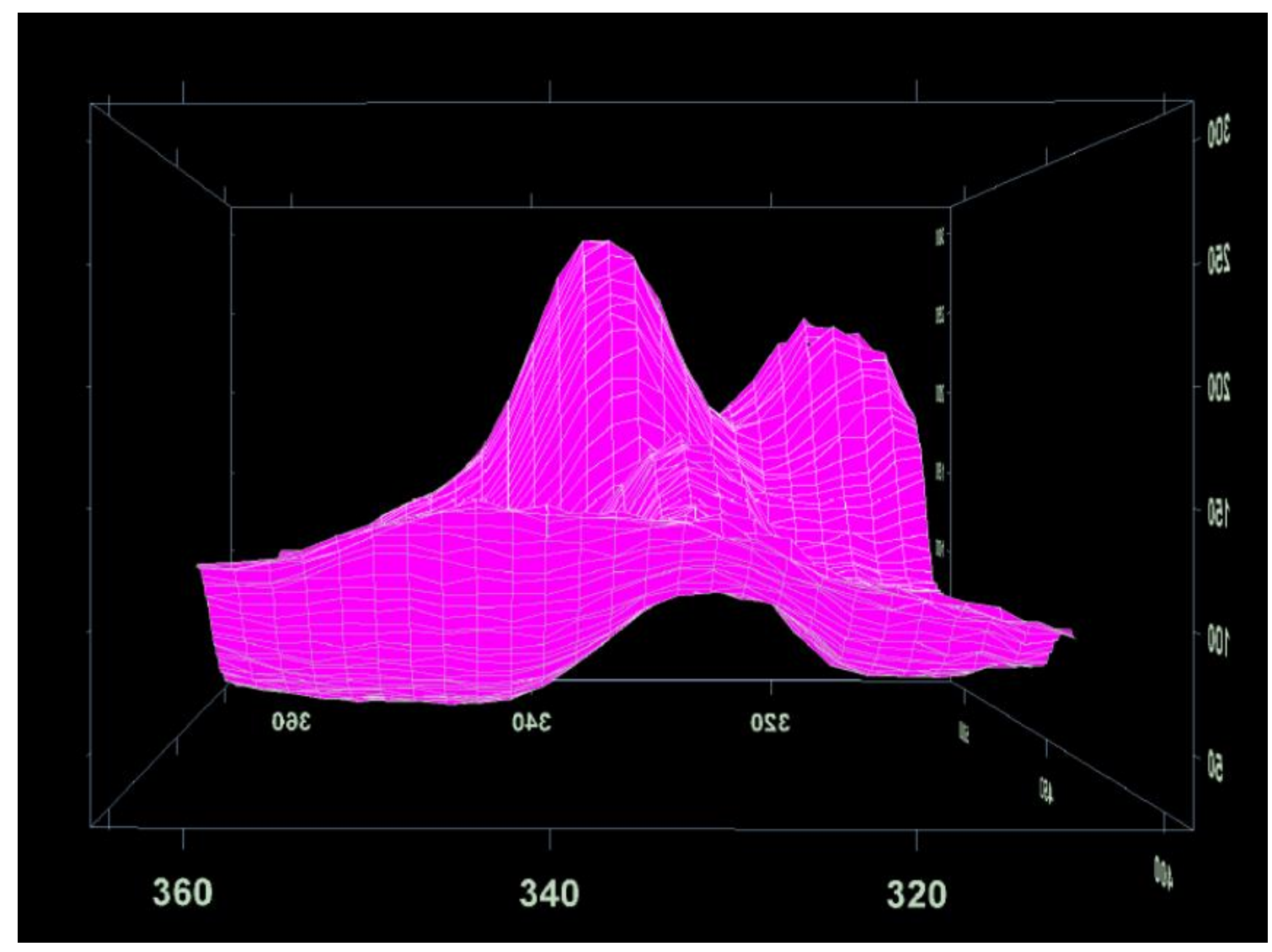

Figure 7. A pseudo 3D topographical image of the 3D fluorescence spectroscopy showing the relative emission intensity of 4-BT for a series of excitation wavelengths from 310 to $360 \mathrm{~nm}$ in $5 \mathrm{~nm}$ increments. 


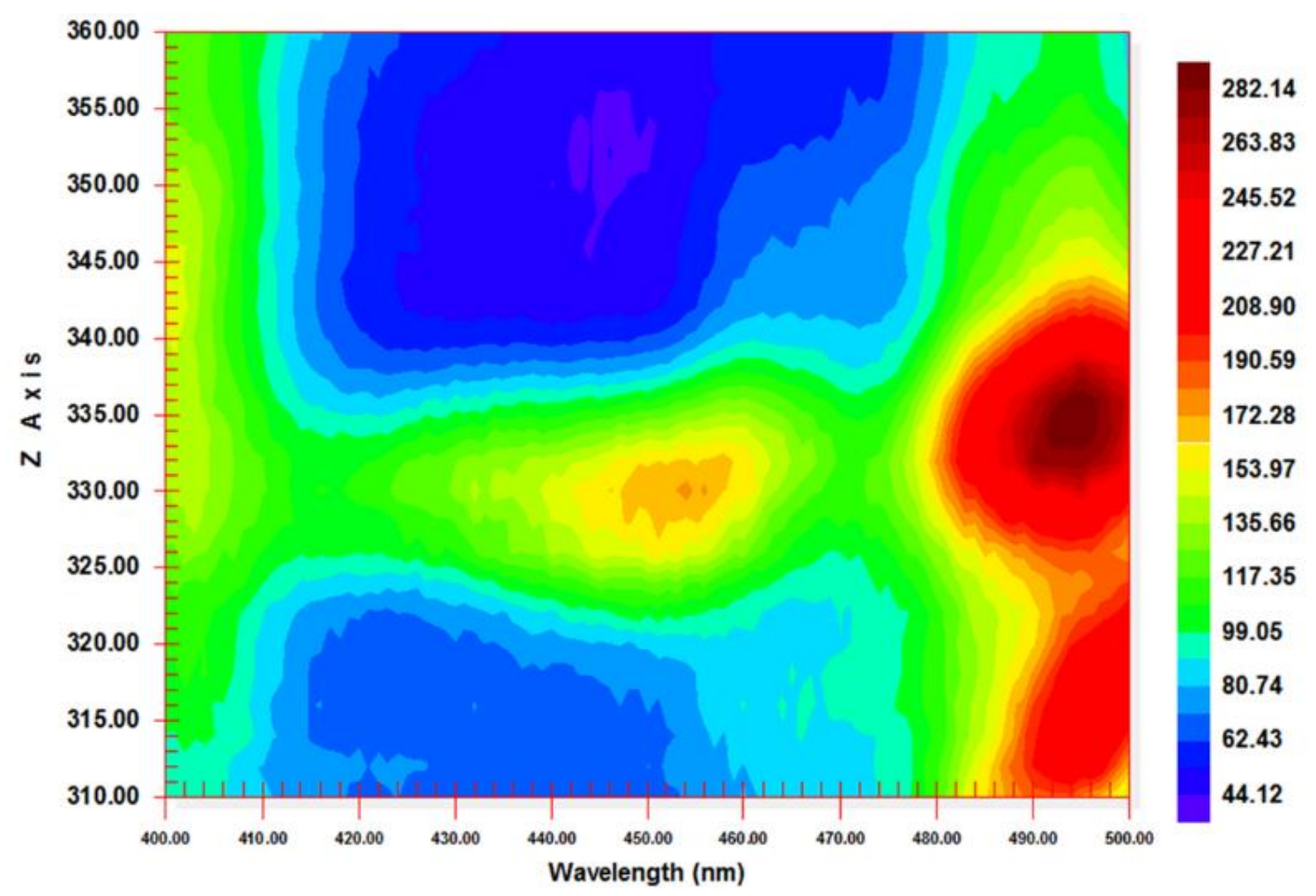

Figure 8. The relative emission intensities of 4-BT shown as a 2D grid of excitation vs. emission wavelength with a coloured contour presentation of the emission intensity.

In support of the now predicted outcomes for 4-BT being driven, not by photo-induced isomerism, but rather access a triplet state via VER, we always performed DFT focusing on calculating the excited emission states for 2-BT and 4-BT.

\section{DFT Calculations}

The electronic structures of both 2-BT and 4-BT were simulated using the Gaussian09 density functional theory software package. ${ }^{88}$ The calculations were performed using the Becke 3parameter Lee-Yang-Parr (B3LYP) hybrid functional ${ }^{89}$ and the electrons were modelled using the def2-SVP basis set. ${ }^{90}$ The simulations were performed using the PCM solvent model using methanol as the solvent. ${ }^{91}$ The absorption spectra were simulated using the time dependentDFT (TD-DFT) framework. ${ }^{92}$ 
Given the similarities in the structures of the two systems, it is not surprising that the simulated electronic structures are equally similar. However, when the predicted transitions were investigated, there was a clear difference between the orbitals involved in the electronic transitions between the two molecules. In the case of 2-BT, the strongest and lowest energy transitions primarily involve the HOMO and HOMO-2 $\rightarrow$ LUMO and LUMO+2 orbitals, which represents a clear MLCT-type of transition. However, in the case of 4-BT there is a significant contribution from the HOMO-3 $\rightarrow$ LUMO transition, which represents a LMCT transition. It is important to note that the HOMO $\rightarrow$ LUMO and LUMO+2 transitions are also observed in 4-BT. Therefore, there is a significantly more of a contribution from the ligands in the case of 4-BT compared to 2-BT, which might give rise to the observed electronic behaviour.

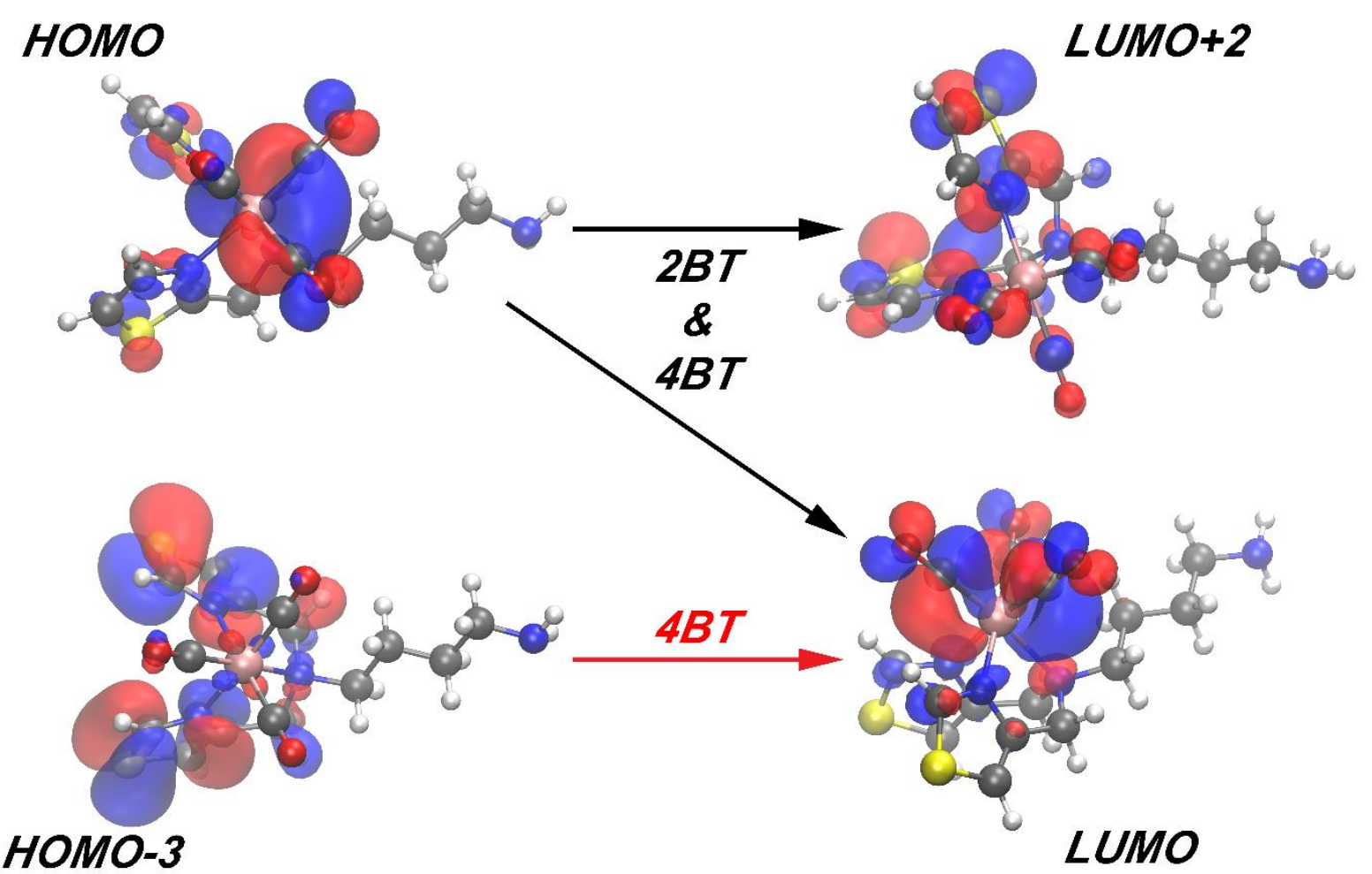

Figure 9. Relevant orbitals to the absorption process in the two studied BT derivatives. The top two molecules are 2-BT, while the lower two are 4-BT. It is important to note that the orbitals are quantitatively similar between the two systems, both in their energetic ordering and spatial nature. 


\begin{tabular}{|c|c|c|c|c|c|}
\hline & Transition & $\begin{array}{l}\text { Occupied } \\
\text { Orbital(s) }\end{array}$ & $\begin{array}{c}\text { Unoccupied } \\
\text { Orbital(s) }\end{array}$ & ? (nm) & $\begin{array}{c}\text { ? }\left(\mathrm{cm}^{-1} \mathrm{M}-\right. \\
1)\end{array}$ \\
\hline \multirow{3}{*}{ 2-BT } & 1 & HOMO & LUMO,+2 & 319.02 & 3279.69 \\
\hline & 2 & HOMO-2 & LUMO,+2 & 309.39 & 76.93 \\
\hline & 3 & $\begin{array}{l}\text { HOMO-2 } \\
\text { HOMO }\end{array}$ & $\begin{array}{c}\text { LUMO,+2 } \\
\text { LUMO },+1,+2,+3\end{array}$ & 293.85 & 234.84 \\
\hline \multirow{3}{*}{ 4-BT } & 1 & HOMO-3 & LUMO & 310.96 & 2801.91 \\
\hline & 2 & $\begin{array}{l}\text { HOMO-2 } \\
\text { HOMO }\end{array}$ & $\begin{array}{c}\text { LUMO,+2 } \\
\text { LUMO+1, +3 }\end{array}$ & 302.88 & 4.05 \\
\hline & 3 & $\begin{array}{l}\text { HOMO-3 } \\
\text { HOMO }\end{array}$ & $\begin{array}{c}\text { LUMO } \\
\text { LUMO+1,+2,+3 }\end{array}$ & 297.46 & 514.22 \\
\hline
\end{tabular}

Table 1: First three electronic transitions in the studied systems, with the occupied and unoccupied orbitals listed, the corresponding transition wavelength, and the maximum molar extinction coefficient at the resonant energy.

\section{Conclusions}

We have successfully (new synthesis(yields)/structures/DFT/solution +solid state photophysical measurements) that now provide a clearer understanding of what is highly unusual photoinduced emissive behavior for a $\operatorname{Re}(\mathrm{I})$ complex (4-BT). Compared to the isomer 2-BT, 4-BT possesses multiple emissive states which are present upon cooling to 77K. The location of the triplet state in 4-BT is also unusual and present below $500 \mathrm{~nm}$, a region where singlet states from coordinated ligands would be expected to dominate. Solid state experiments and comparisons of 4-BT to the isomer 2-BT suggest that the previously reported hypothesis for the origin of the behavior of 4-BT, structural isomerization upon excitation, is not the case. The 2BT structure would be more energetically favorable to form a Re-S bond upon excitation and a ring flip as there is not the extra carbon spacer that is present in 4-BT. The energy level needed to produce a structural isomer without the presence of solvent would be considerably greater. The observation that the 5-thiazole based ligand, 1,1-bis-5-thiazole-(1,4)-diaminobutane, which is designed to allow coordination only through the sulfur donors, does not provide the analogous $\left[\operatorname{Re}(\mathrm{CO})_{3}-1,1\right.$-bis-5-thiazole-(1,4)-diaminobutane) $] \mathrm{Br}(5-\mathrm{BT})$, even under the most forcing conditions, supports this conclusion. Since the behavior of 4-BT also carries over to the 
solid state, it is likely that 4-BT is unique in its ability to emit from multiple states dependent upon excitation.

Since the results of this study indicate that photoinduced isomerization to a mixture of linkage isomers with discrete emission characteristics and electronic states is not the cause of the emission variation with input variation observed for 4-BT, an alternative hypothesis must be proposed and tested. Consequently, the observed behavior may arise as a consequence of vibrational energy relaxation (VER) (including intramolecular vibrational energy redistribution (IVR) and vibrational cooling (VC)). However, this is not a trivial task due to the complicated excited-state potential energy surfaces (PES) of these complexes and multiple photoinduced energy relaxation processes with different timescales following photoexcitation. Ultrafast laser spectroscopy techniques with sub-picosecond temporal resolution are capable of providing quantitative and quantum-state-resolved information of the PESs and energy relaxation dynamics that can elucidate at the molecular level mechanisms that govern photophysical properties of the target systems. These studies will be described in a future publication.

\section{References}

1. K. E. Henry, R. G. Balasingham, A. R. Vortherms, J. A. Platts, J. F. Valliant, M. P. Coogan, J. Zubieta, R. P. Doyle, Chem. Sci., 2013, 4, 2490.

2. M. P. Coogan, R. P. Doyle, J. F. Valliant, J. Zubieta, J. Labeld. Comp. Radiopharm., 2013, 2014, 57, 255.

3. M. S. Lowry, W. R. Hudson, R. A. Pascal, Jr., S. Bernhard, J. Am. Chem. Soc., 2004, 126, 14129.

4. A. Juris, V. Balzani, F. Barigelletti, S. Campagna, P. Belser, A. Von Zelewsky, Coord. Chem. Rev., 1988, 84, 85. 
5. V. Balzani, A. Juris, M. Venturi, S. Campagna, S. Serroni, Chem. Rev., 1996, 96, 59.

6. K. K.-W. Lo, S. P.-Y. Li, K. Y. Zhang, New J. Chem., 2011, 35, 265.

7. S. V. Eliseeva, J.-C. G. Bünzli , Chem. Soc. Rev., 2010, 39, 189.

8. D. J. Stufkens, Comments Inorg. Chem, 1992, 13, 359.

9. D. J. Stufkens, A. Vlcek, Jr., Coord. Chem. Rev., 1998, 177, 127.

10. D. R. Striplin, G. A. Crosby, Coord. Chem. Rev., 2001, 211, 163.

11. A. J. Lees, S.-S. Sun, in Comprehensive Coordination Chemistry II, 2004, vol. 2, pp. 731.

12. K. K.-W. Lo, K. Y. Zhang, S. P.-Y. Li, Eur. J. Inorg. Chem., 2011, 3551.

13. R. G. Balasingham, M. P. Coogan, F. L. Thorp-Greenwood, Dalton Trans., 2011, 40, 11663.

14. V. W.-W. Yam, K. M.-C. Wong, Chem. Comm., 2011, 47, 11579.

15. S.-S. Sun, A. J. Lees, Coord. Chem. Rev., 2002, 230, 171.

16. B. Machura, M. Wolff, E. Benoist, Y. Coulais, J. Organometal. Chem., 2013, 724, 82.

17. M. Kazanuma, E. Gindensperger, C. Daniel, Dalton Trans., 2012, 41, 13191.

18. T. Morimoto, M. Ito, K. Koike, T. Kojima, T. Ozeki, O. Ishitani, Chem. Eur. J., 2012, 18, 3292. 
19. K. Potgieter, P. Mayer, T. Gerber, N. Yumato, E. Hosten, I. Booysen, R. Betz, M. Ismail, B. van Brecht, Polyhedron, 2013, 49, 67.

20. A. J. Hallett, J. A. Pope, Inorg. Chem. Commun., 2011, 14, 1606.

21. B. S. Uppal, R. K. Booth, N. Ali, C. Lockwood, C. R. Rice, P. I. P. Elliott, Dalton Trans., 2011, 40, 7610.

22. Q.-H. Wei, F.-N. Xiao, L.-J. Han, S.-L. Zeng, Y.-N. Duan, G.-N. Chen, Dalton Trans., 2011, 40, 5078.

23. B. Machura, M. Wolff, I. Gryca, A. Palion, K. Michalik, Polyhedron, 2011, 30, 2275.

24. A. Carreno, A. E. Aros, C. Otero, R. Polanco, M. Gacitua, R. Arratia-Perez, J. A. Fuentes, New J. Chem., 2017, 41, 2140.

25. L. J. Raszeja, D. Siegmund, A. L. Cordes, J. Gueldenhaupt, K. Gerwert, S. Hahn, N. Metzler-Nolte, Chem. Commun., 2017, 53, 905.

26. S. Hostachy, J.-M. Swiecicki, C. Sandt, N. Delsuc, C. Policar, Dalton Trans., 2016, 45, 2791.

27. A. J. North, D. J. Hayne, C. Schieber, K. Price, A. R. White, P. J. Crouch, A.; Rigopoulos, G. J. O'Keefe, H. Tochon-Danguy, A. M. Scott, J. M. White, U. Ackermann, P. S. Donnelly, Inorg. Chem., 2015, 54, 9594.

28. R. H. Platel, M. P. Coogan, J. A. Platts, Dalton Trans., 2015, 44, 11700. 
29. M. K. Mbagu, D. N. Kebulu, A. Winstead, S. K. Pramanik, H. N. Banerjee, M. O. Iwunze, J. M. Wachira, G. E. Greco, G. K. Haynes, A. Sehmer, F. H. Sarkar, D. M. Ho, R. D. Pike, S. K. Mandal, Inorg. Chem. Commun., 2012, 21, 35.

30. M. D. Bartholoma, A. S. Louie, J. F. Valliant, J. Zubieta, Chem. Rev., 2010, 10, 2903.

31. M. Bartholoma, J. Valliant, K. P. Maresca, J. Babich, J. Zubieta, Chem. Comm., 2009, 493.

32. K. A. Stephenson, J. Zubieta, S. R. Banerjee, M. K. Levadala, L. Taggart, L. Ryan, N. McFarlane, D. R. Boreham, J. W. Babich, J. F. Valliant, Bioconj. Chem., 2004, 15, 128.

33. S. R. Banerjee, L. Francesconi, J. Valliant, J. W. Babich, J. Zubieta, Nucl. Med. Biol., $2005,32,1$.

34. S. R. Banerjee, N. Lazarova, K. M. Levadala, J. Valliant, K. Stephenson, K. P. Maresca, J. Zubieta, J. W. Babich, Technetium, Rhenium and Other Metals in Chemistry and Nuclear Medicine, 6, M. Nicolini, U. Mazzi, eds., Servizi Grafici Editoriali pnc, Padova, Italy, 2002, 111.

35. S. R. Banerjee, M. K. Levadala, N. Lazarova, L. Wei, J. F. Valliant, K. A. Stephenson, J. W. Babich, K. P. Maresca, J. Zubieta, Inorg. Chem., 2002, 41, 6417.

36. K. A. Stephenson, S. R. Banerjee, O. O. Sogbein, M. K. Levadala, N. McFarlane, D. R. Boreham, K. P. Maresca, J. W. Babich, J. Zubieta, J. F. Valliant, Bioconj. Chem., 2005, 16, 1189.

37. K. A. Stephenson, S. R. Banerjee, T. Besanger, O. Sogbein, M. K. Levadala, N. McFarlane, J. A. Lemon, D. R. Boreham, K. P. Maresca, J. D. Brennan, J. W. Babich, J. Zubieta, J. F. Valliant, J. Am. Chem. Soc., 2004, 126, 8598. 
38. K. A. Stephenson, S. R. Banerjee, N. Mcfarlane, D. R. Boreham, K. P. Maresca, J. W. Babich, J. Zubieta, J. F. Valliant, Can. J. Chem., 2006, 83, 2060.

39. A. F.Armstrong, N. Oakley, S. Parker, P. W. Causey, P. J. Lemon, A. Capretta, C. Zimmerman, J. Joyal, F. Appoh, J. Zubieta, J. W. Babich, G. Singh, J. F. Valliant, Chem. Comm., $2008,5532$.

40. M. K. Levadala, S. R. Banerjee, K. P. Maresca, J. W. Babich, J. Zubieta, Synthesis, 2004, 1759.

41. S. R. Banerjee, L. Wei, M. K. Levadala, N. Lazarova, V. O. Golub, C. L. O'Connor, K. A. Stephenson, J. F. Valliant, J. W. Babich, J. Zubieta, Inorg. Chem., 2002, 41, 5795.

42. L. Wei, S. Ray, M. K. Levadala, J. Babich, J.; Zubieta, Inorg. Chem. Commun., 2003, 6, 1099.

43. L. Wei, S. R. Banerjee, M. K. Levadala, J. Babich, J. Zubieta, Inorg. Chim. Acta, 2004, 357, 1499.

44. S. R. Banerjee, J. W. Babich, J. Zubieta, Inorg. Chem. Commun., 2004, 7, 481.

45. S. R. Banerjee, J. W. Babich, J. Zubieta, Chem. Comm., 2005, 1784.

46. L. Wei, J. Babich, W. C. Eckelman, J. Zubieta, Inorg. Chem., 2005, 44, 2198.

47. L. Wei, J. Babich, J. Zubieta, Inorg. Chim. Acta, 2005, 358, 3691.

48. S. R. Banerjee, K. P. Maresca, J. W. Babich, W. A. Graham, M. Barzana, Q. Dong, A. J. Fischman, J. Zubieta, Bioconj. Chem., 2005, 16, 885. 
49. N. Lazarova, J. Babich, J. F. Valliant, P. Schaffer, S. James, J. Zubieta, Inorg. Chem., 2005, 44, 6773.

50. S. R. Banerjee, J. W. Babich, J. F. Valliant, J. Zubieta, Dalton Trans., 2005, 3886.

51. L. Wei, J. W. Babich, J. Zubieta, Inorg. Chem., 2006, 45, 3057.

52. S. James, K. Maresca, J. Babich, J. Valliant, L. Doering, J. Zubieta, Bioconj. Chem., 2006, 17,590 .

53. S. James, K. P. Maresca, D. G. Allis, J. Valliant, W. Eckelman, J. Babich, J. Zubieta, Bioconj. Chem., 2006, 17, 579.

54. K. P. Maresca, J. F. Kronauge, J. Zubieta, J. W. Babich, Inorg. Chem. Commun., 2007, 1409.

55. P. Schaffer, J. A. Gleave, J. A. Lemon, L. C. Reid, L. K. K. Pacey, T. H. Farncombe, D. R. Boreham, J. Zubieta, J. W. Babich, L. C. Doering, J. F. Valliant, Nuclear Medicine and Biology, 2008, 35, 159.

56. K. A. Stephenson, L. C. Reid, J. Zubieta, J. W. Babich, M.-P. Kung, H. F. Kung, J. F. Valliant, Bioconj. Chem., 2008, 19, 1087.

57. N. Viola-Villegas, A. E. Rabindeau, J. Cesnavicius, J. Zubieta, R. P. Doyle, ChemMedChem., 2008, 3, 1387. 
58. K. P. Maresca, S. M. Hillier, F. J. Femia, C. N. Zimmerman, M. K.; Levadala, S. R. Banerjee, J. Hicks, C. Sundararajan, J. Valliant, J. Zubieta, W. C. Eckelman, J. L. Joyal, J. W. Babich, Bioconj. Chem., 2009, 20, 1625.

59. N. Viola-Villegas, A. E. Rabideau, M. Bartholoma, J. Zubieta, R. P. Doyle, J. Med. Chem., 2009, 52, 5253.

60. C. Sundararajan, T. R. Besanger, R. Labiris, K. J. Guenther, T. Strack, R. Garafalo, T. T. Kawabata, D. Finco-Kent, J. Zubieta, J. W. Babich, J. F. Valliant, J. Med. Chem., 2010, 53, 2612.

61. M. D. Bartholomae, A. R. Vortherms, S. Hillier, B. Ploier, J. Joyal, J. Babich, R. P. Doyle, J. Zubieta, ChemMedChem., 2010, 5, 1513.

62. M. D. Bartholomae, A. R. Vortherms, S. Hillier, J. Joyal, J. Babich, R. P. Doyle, J. Zubieta, Dalton Trans., 2011, 40, 6216.

63. A. R. Vortherms, A. R. Kahkoska, A. E. Rabindeau, J. Zubieta, L. L. Andersen, M. Madsen, R. P. Doyle, Chem. Comm., 2011, 47, 9792.

64. K. E. Henry, R. G. Balasingham, A. R. Vortherms, J. A. Platts, J. F. Valliant, M. P. Coogan, J. Zubieta, R. P. Doyle, Chem. Sci., 2013, 4, 2490.

65. R. G. Balasingham, M. P. Coogan, F. L. Thorp-Greenwood, Dalton Trans., 20111, 40, 11663.

66. K. K.-W. Lo, Top. Organomet. Chem. 2010, 29, 115.

67. K. K.-W. Lo, A. W.-T. Choi, W. H.-T. Law, Dalton Trans., 2012, 41, 6021. 
68. R. Waibel, H. Treichler, N. G. Scharfer, D. R. van Staveren, S. Mundwiler, S. Kunze, M. Küenzi, R. Alberto, J. Nüesch, A. Knuth, H. Moch, R. Schibli, P. A. Schubiger, Cancer Res., 2008, 68, 2904.

69. B. Spingler, S. Mundwiler, P. Ruiz-Sánchez, D. R. van Staveren, R. Alberto, Eur. J. Inorg. Chem., 2007, 2641.

70. R. Akuja, R. Yammani, J. A. Bauer, S. Kalra, S. Seetharam, B. Seetharam, Biochem. J., $2008,410,301$.

71. E. I. Christensen, H. Birn, Am. J. Physiol., Renal Physiol., 2001, 280, F562.

72. M. Kasha, M., Discuss. Faraday Soc., 1950, 9, 14.

73. N. J. Turro, Modern molecular photochemistry, Benjamin/Cummings: Menlo Park, Ca. 1978.

74. G. Brancato, G. Signore, P. Neyroz, D. Polli, G. Cerullo, G. Abbandonato, L. Nucara, V. Barone, F. Beltram, R. Bizzarri, J. Phys. Chem. B, 2015, 119, 6144.

75. K. Costuas, A. Garreau, A. Bulou, B. Fontaine, J. Cuny, R. Gautier, M. Mortier Y. Molard, J.-L. Duvail, E. Faulques, S. Cordier, Phys.Chem.Chem.Phys., 2015, 17, 28574.

76. H.-W. Tseng, J.-Y. Shen, T.-Y. Kuo, T.-S. Tu, Y.-A. Chen, A. P. Demchenko, P.-T. Chou, Chem. Sci., 2016, 7, 655.

77. APEX2, Data Collection Software, version 2011.8-0, Bruker-AXS Inc., Madison, WI 2011.

78. SAINT plus, Data Reduction Software, version 6.45A, Bruker-AXS Inc., Madison, WI 2013.

79. G. M. Sheldrick, SADABS, University of Göttingen, 1996.

80. SHELXTL PC, version 6.12, Bruker-AXS Inc., Madison, WI, 2002. 
81. CrystalMaker ${ }^{\circledast}$ : a crystal and molecular structures program. CrystalMaker Software Ltd., Oxford, England (www.crystalmaker.com).

82. B. Machura, M. Wolff, E. Benoist, Y. Coulais, Y., J. Organometal. Chem., 2013, 724, 82.

83. A. Albertino, C. Garino, S. Ghiani, R. Gobetto, C. Nervi, L. Salasa, E. Rosenberg, A.

Sharmin, G. Viscardi, R. Busciano, G. Croce, M. Milanesio, J. Organometal. Chem., 2007, 692, 1377.

84. M. Sobiesiak, T. Muzioł, M. Rozalski, U. Krajewskac, E, Budzisz, New J. Chem., 2014, 38, 5349.

85. J. M. Ellsworth, C.-Y. Su, Z. Khaliq, R. E. Hipp, A. M. Goforth, M. D. Smith, H.-C. zur Loye, J. Mol. Struct., 2006, 796, 86.

86. X.-J. Tan, H.-Z. Liu, C.-Z. Ye, J.-F. Lou, Y. Liu, D.-X. Xing, S.-P. Li, S.-L. Liu, L.-Z. Song, Polyhedron, 2014, 71, 119.

87. S. A. Moya, J. Guerrero, R. Pastene, R. Schmidt, R. Sariego, R. Sartori, J. Sanz-Aparicio, I. Fonseca, M. Martinez-Ripoli, Inorg. Chem., 1994, 33, 2341.

88. Gaussian 09, Revision A.02, M. J. Frisch, G. W. Trucks, H. B. Schlegel, G. E. Scuseria, M. A. Robb, J. R. Cheeseman, G. Scalmani, V. Barone, G. A. Petersson, H. Nakatsuji, X. Li, M. Caricato, A. Marenich, J. Bloino, B. G. Janesko, R. Gomperts, B. Mennucci, H. P. Hratchian, J. V. Ortiz, A. F. Izmaylov, J. L. Sonnenberg, D. Williams-Young, F. Ding, F. Lipparini, F. Egidi, J. Goings, B. Peng, A. Petrone, T. Henderson, D. Ranasinghe, V. G. Zakrzewski, J. Gao, N. Rega, G. Zheng, W. Liang, M. Hada, M. Ehara, K. Toyota, R. Fukuda, J. Hasegawa, M. Ishida, T. Nakajima, Y. Honda, O. Kitao, H. Nakai, T. Vreven, K. Throssell, J. A. Montgomery, Jr., J. E. Peralta, F. Ogliaro, M. Bearpark, J. J. Heyd, E. Brothers, K. N. Kudin, V. N. Staroverov, T. Keith, R. Kobayashi, J. Normand, K. Raghavachari, A. Rendell, J. C. Burant, S. S. Iyengar, J. Tomasi, M. Cossi, J. M. Millam, M. Klene, C. Adamo, R. Cammi, J. W. Ochterski, R. L. Martin, K. Morokuma, O. Farkas, J. B. Foresman, and D. J. Fox, Gaussian, Inc., Wallingford CT, 2016.

89. A. D. Becke, J. Chem. Phys. 1993,98, 5652..

90. F. Weigend, R. Ahlrichs, Phys. Chem. Chem. Phys., 2005, 7, 3297. 
91. J. Tomasi, B. Mennucci, R. Cammi, Chem. Rev., 2005, 105, 2999.

92. C. Adamo, D. Jacquemin, Chem. Soc. Rev., 2013, 42, 845.

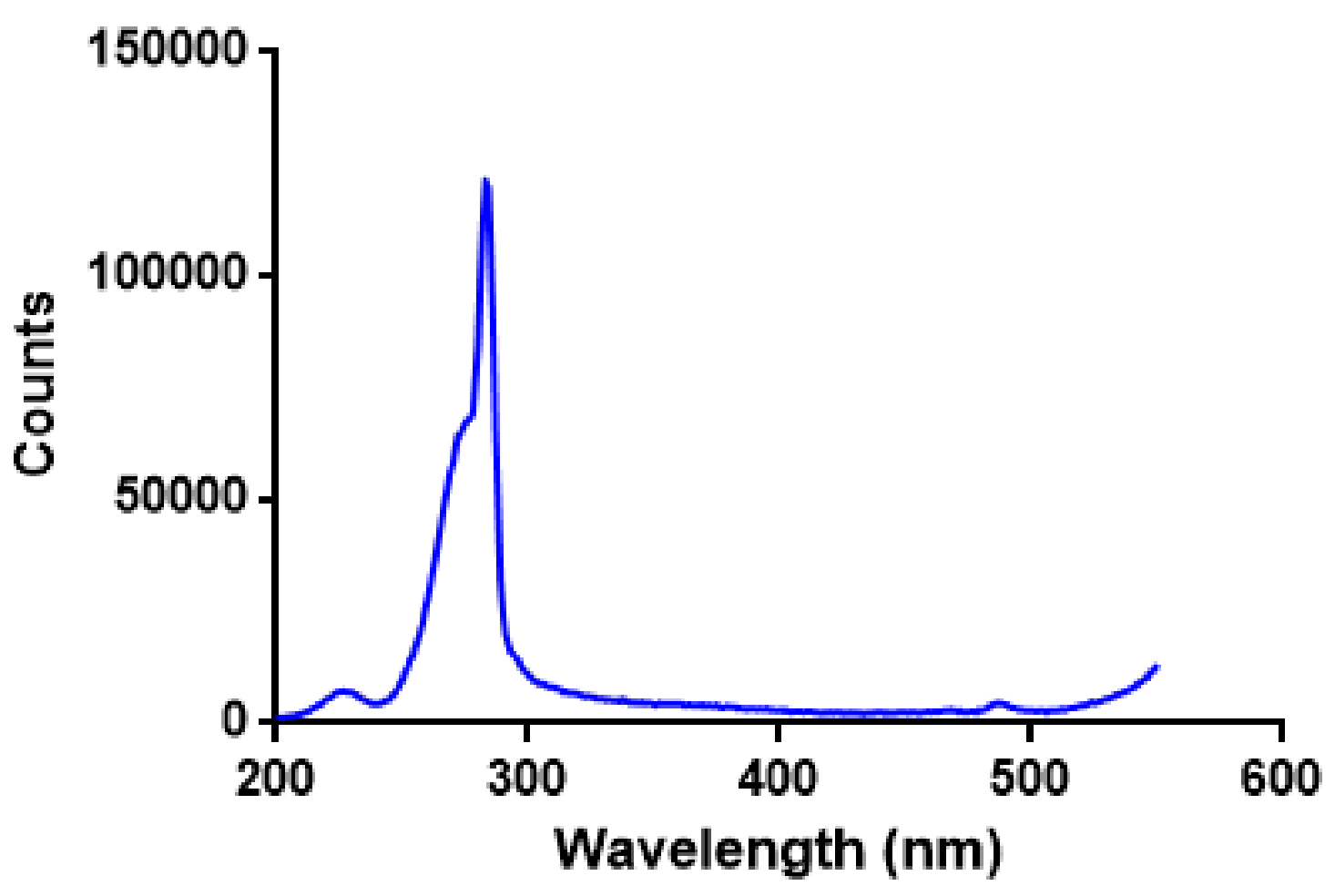

This excitation scan at $570 \mathrm{~nm}$ shows that contributions are from across the whole absorption. This suggest that this is our lowest excited stated however the lifetime (5ns) and the low intensity suggests that it is quenched. 
